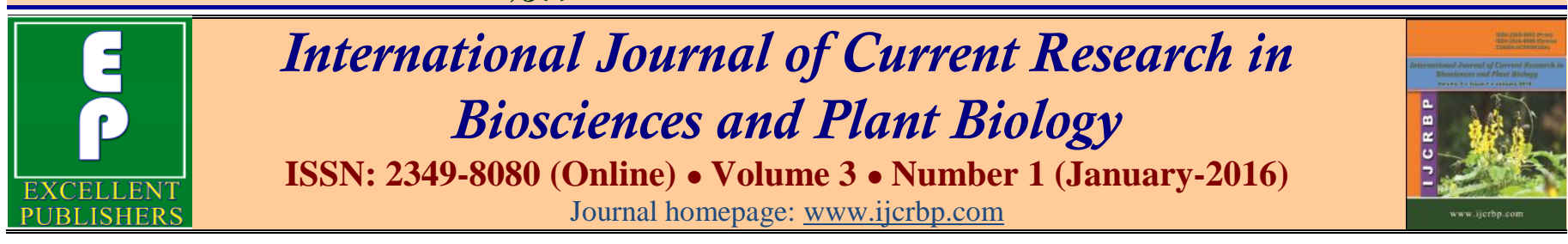

\title{
Structure and Floristic Diversity of the Woody Vegetation of the Mount Kupe Submontane Forest (Moungo - Cameroon)
}

\author{
Tchetgnia Jean Mérimée Tchoua ${ }^{1 *}$ and Emmanuel Noumi² \\ ${ }^{1}$ Department of plant Biology: Faculty of Science, University of Yaoundé I; P. O. Box. 812 Yaoundé, Cameroon \\ ${ }^{2}$ Laboratory of Plant Biology: Higher Teachers' Training College, University of Yaoundé I; P. O. Box. 47, Yaoundé, Cameroon
}

*Corresponding author.

\begin{abstract}
This study aims to evaluate the vegetation structure and diversity of woody species in the sub mountain forest of Mount Koupe (Moungo-Cameroon) between 1000 and 1800 $\mathrm{m}$ and to appreciate the index values obtained with those of the tropic, Malagasy and Neotropical region of the world. The basic data have been obtained on inventory of 1-ha plot taking into account all trees whose diameter at breast height $(\mathrm{dbh}) \geq 10 \mathrm{~cm}$. The parameters of floristic diversity were calculated using the standard methodology. A total of 1184 individuals belonging to 156 species, 114 genera and 51 families were inventoried, with the total basal area of $151.44 \mathrm{~m}^{2} / \mathrm{ha}$. Most individuals (trees) had between 10 and $20 \mathrm{~m}$ height with diameter between 50 and $80 \mathrm{~cm}$, but relatively a significant number of individuals (05) reached even higher values, up to $30 \mathrm{~m}$ height and $135 \mathrm{~cm}$ of diameter. The five most important families in terms of density, diversity and dominance were Meliaceae, Euphorbiaceae, Rubiaceae, Malvaceae and Burseraceae. They represent $52.53 \%$ of the Family Important Value (FIV). The specific composition revealed that 10 species dominate the submontane forest, $6.41 \%$ of species represent $54.50 \%$ of the Index of Value Importance (IVI). They are Carapa procera, Santiria trimera, Strombosia pustulata, Cola acuminata, Turraeanthus africana, Penianthus longifolius, Allanblackia gabonensis, Drypetes leonensis, Pycnanthus angolensis and Sorindeia grandifolia. A fraction of species (70) then 44.87 $\%$ is represented by one individual. In conclusion, the Kupe submontane forest is marked down substantially to the lowland forest. The family of Leguminosae which dominate in these levels does not occur among the 10 important families in FIV; they come in the $14^{\text {th }}$ position. The Rubiaceae occupies $1^{\text {st }}$ position in in relative diversity and $2^{\text {nd }}$ position in FIV mark in this altitudinal stretch.
\end{abstract}

\section{Article Info}

Accepted: 27 November 2015

Available Online: 06 January 2016

\section{Keywords}

Kupe Mountain

Plant diversity

Submontane forest

Vegetation structure

Woody species

\section{Introduction}

The Kupe Mountain (2064 m altitude) has a submontane forest between $800 \mathrm{~m}-1800 \mathrm{~m}$ altitude, belonging to the Guinean-Congolese region (Letouzey, 1985). One notes that the Cameroonian Mountains with the specific example of Mount Kupe belong to the Cameroon afromontane archipelagos which are connected comfortably (from the floristic point of view) to the other archipelago highlands of East and Southern Africa (White, 1983). The submontane storey in Cameroon has witnessed several phytosociological studies (Noumi, 1998; Noumi and Amougou, 2003) and phytogeographical studies (Noumi, 2012, 2013, 2015; Madiapevo, 2008; Tagne, 2007; Tchoua, 2013). These studies established the individual groups and syntaxa in part and also led to the determination of the families' and species' quantitative parameters for these types of forests. 
These works although are concerned only with the low levels of submontane storey heights reach. They do not cover the whole altitude of the submontane storey and are not therefore representative of the entire zone. This research therefore attempts to answer the question: "Are the characteristic parameters of the structure and diversity of the Mount Kupe submontane forest different from those of previously determined parameters in the highland forests?"

The purpose of the study is sample the Kupe forest by sampling biplots, taking into account trees with diameter at breast height $(\mathrm{DBH}) \geq 10 \mathrm{~cm}$, to establish quantitatively its parameters of diversity and to characterize the forest compared to the known data of the African, Asiatic and neotropical forests.

\section{Materials and methods}

\section{Study Area}

The Kupe massif $\left(4^{0} 44^{\prime}-4^{0} 52^{\prime}\right.$ latitude North and $9^{0}$ $41^{\prime}-9^{0} 52$ ' longitude East) covers a planimetric surface area of 210ha thereabout. It is formed by the outfit of three summits: «Nature trail», «Mean trail» and «Maxis trail». This last-mentioned, is the highest and reaches 2064 metres at its highest point (Fig. 1). Several villages surround the massif: Nsuke, Mbulle, Bendume, Mpacko, Tape-Etube, Ndom and Nyassosso (on the South West regional side); Ngab, N'lohé, Lala and Kola (on the Littoral regional side). The Mount is a volcanotectonic horst (Lamilen et al., 1998) with irregular shapes. The geology of the summit is essentially constituted of granitic volcanic formations giving a ferruginous soil (Lamilen et al., 1998). They are characterised more or less by the abundance of fragments of deteriorating basalt (Geze, 1943).

The Kupe Mountain belongs to the bioclimatic zone of the mountains and high lands of West Cameroon within the submontane domain of the Guinean-Congolese phytogeographic region (Letouzey, 1968). Temperatures are curbed and thermal amplitudes are high (Melingui, 1989). The yearly average temperature is $20^{\circ} \mathrm{C}$. The Kupe mountain is subjected to the humid wind (monsoon) coming from the Atlantic Ocean, and to the incursions of the tropical air of the Sahara (harmattan). The meeting of these two masses of air forms the Intertropical Front (ITF) whose swing determines the cycle of the seasons. The yearly rainfall varies from $73 \mathrm{~mm}$ to $878 \mathrm{~mm}$ (Fig. 2) with a yearly average of $4891 \mathrm{~mm}$. The climate is tropical, with 2 seasons: a dry season from November to April and a rainy season from May to October (Suchel, 1987). Relative humidity is very high on the mountain and reaches a mean of $87 \%$ (Tchiengué, 2004).
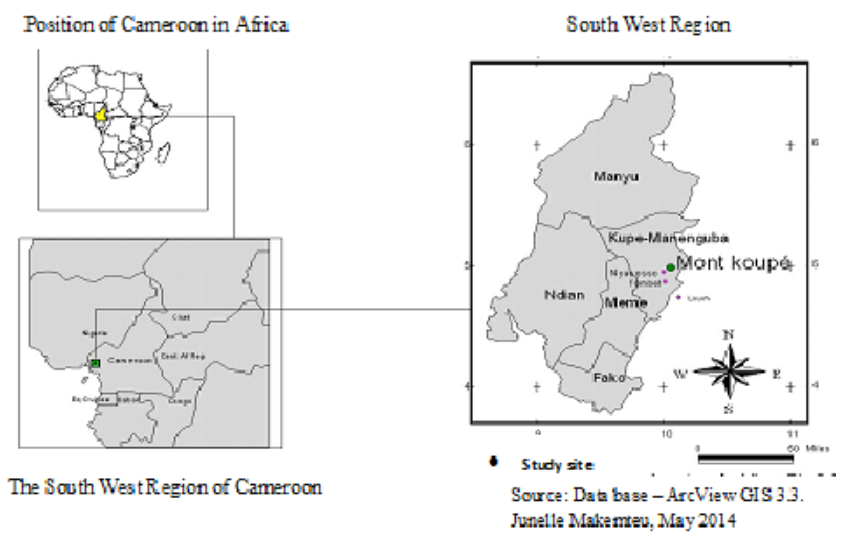

Fig. 1: Map of the location of Mount Kupe (Source: Makemteu, 2014).

\section{Methodology}

A quantitative inventory of 1ha surface area was achieved using a biplot of rectangular dimensions $(25 \mathrm{~m}$ by $40 \mathrm{~m}$ ), taking into account all trees of which the DBH at $1.30 \mathrm{~cm}$ above soil was $\geq 10 \mathrm{~cm}$. The plot was chosen from intact an portion representative of the forest. From the information gathered, we represented a diagram of the distribution of the diameters in classes (Noumi, 2012, 2013; Tchoua, 2013; Tagne, 2007) as well as the areaspecies curve (Gounot, 1969). Using the standard methodology (Curtis and Mcintosh, 1950; Dagnelie, 1981) the following parameters were calculated. At specific and family level: relative density and relative dominance; at specific level: relative frequency; at family level only: relative diversity. From these data importance value index (IVI) and Family importance value (FIV) were calculated for species and families, respectively. The basal area, that is, the sum of the area of each tree trunk, was measured at a definite height (Mori et al., 1983; Devineau, 1984; Senterre et al., 2001).

Sampling was conducted in a fractional manner in plots, all identical from the mesologic and physionomic point of view, between 2011 and 2014. The inventory was done and all trees and lianas with $\mathrm{DBH} \geq 10 \mathrm{~cm}$ were taken into acount. The determination of large tree which were inaccessible during data collection was made in situ using the dendrological criteria (Normand, 1965; Vivien and Faure, 1985). All of the 1184 samples harvested were pressed and dried in the Plant Biology Laboratory of the Higher Teacher's Training College of the 
University of Yaounde 1 and the National Herbarium of Cameroon in Yaoundé. Trees were distributed according to classes of $10 \mathrm{~cm}$ diameter; species classification in function of maximum diameter reach was made. The floristic diversity was considered in a synthetic manner through the main physionomic and phytogeographical spectres.

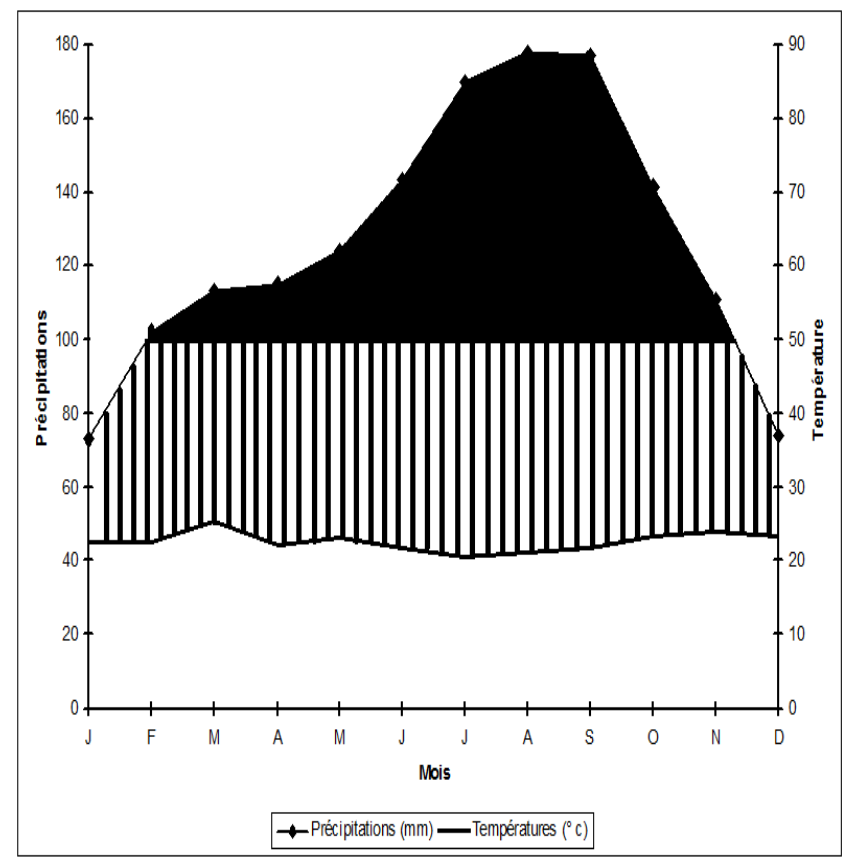

Fig. 2: Ombrothemic diagram. Curve of the monthly mean of rainfalls [scale reduced to the $1 / 10$ from $100 \mathrm{~mm}$, gray part according to the method of Walter and Leith (1964)] and of the monthly mean temperature. Data of the meteorological station of Tombel from 1987 to 1997 . There are no monthly mean values of precipitation and temperature in Nyassosso, but these values must be nearest of those of Tombel station situated 25 $\mathrm{km}$ to the Southern side.

The Biological Types (BT) were distinguished according to the classification of Raunkiaer (1934), done by Schnell (1970). Their types of phytogeographical distribution (TP) were established according to the works of Schnell (1970) for the inter-tropical massif orophytes; according to the works of White (1983) for the big chorological subdivisions of Africa and that of Letouzey (1985) for the phytogeography of Cameroon. The altitude components of the species were established according to Senterre (2005): $\mathrm{Bm}=$ species of low and middle altitude; $\mathrm{Sm}=$ species of submontane forest or submontane floor; $\mathrm{Mi}=$ species of lower highland forest or lower highland floor or humid highland floor. The categories were deducted from the characteristics of the species. Only the intermediate combination between two successive types of the pressure gradient (none disconnected) was generally feasible. The combination of the phytogeographical distribution and the components elevation enabled an orophytic species to be better situated in different chorological area (Schnell, 1970; Noumi, 2012, 2013).

\section{Floristic analysis}

In order to compare the sample realised with the others studies, the following indices of diversity were calculated:

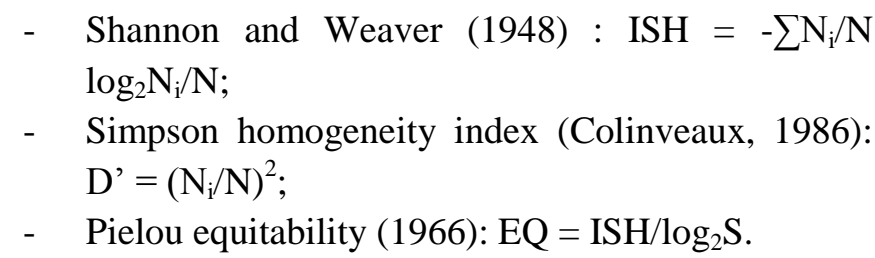

Where: $\mathrm{N}_{\mathrm{I}}$ is the strength of the species "I" and $\mathrm{N}$ the strength of all species. ISH is expressed in bits. $\mathrm{S}$ is the number of species present on the plots.

\section{Results}

\section{Floristic composition}

The floristic inventories carried out a 1 ha plot in the Mount Kupe submontane forest resulted in a census of 1184 individuals (trees and lianas) at $\mathrm{dbh} \geq 10 \mathrm{~cm}$ representing 156 species regrouped into 114 genera and 51 families (Appendix 1). Only one species was determined at the family level.

The most diversified families were Rubiaceae, (17 species and 12 genera), Euphorbiaceae (12; 9), Annonaceae $(11 ; 9)$ and Sapindaceae $(9 ; 5)$ (Table 1). In general, this vegetation is dominated by shrubby species $(74$, at least $47 \%)$ and the treelike species (51, at least $32 \%)$. The proportion of shrub (20, at least $12 \%)$ was low and similar to that of creeper species (11, at least $7 \%$ ). The species censused in this submontane vegetation were regrouped into five different biological types. The distribution of species number according to families showed an inverted "J" shaped curve (Fig. 3). The number of species inventoried by plots of 0.1 ha varied from 25 to 42 with an average of 34 species per plot. The total basal area attained was $151.44 \mathrm{~m}^{2} / \mathrm{ha}$. From the morphological point of view, the classification of species in function of diameter showed five categories (A, B, C, D, and E) of whole vertical strata. According to the individual diameter, the maximum dbh 
was $185 \mathrm{~cm}$, a value reached by only an individual (Carapa procera). 822 individuals representing 69.43\% encountered in the inventory had a diameter between $10 \mathrm{~cm}-30 \mathrm{~cm} ; 23.06 \%$ had diameter between $30 \mathrm{~cm}$ -
$70 \mathrm{~cm}$ and $6.67 \%$ had diameter between $70 \mathrm{~cm}-130 \mathrm{~cm}$. One of the lower proportion individuals representing $8.4 \%$ of the species inventoried had a large dbh $(>130 \mathrm{~cm})$.

Table 1. Diversity of 51 families in function of species.

\begin{tabular}{|c|c|c|c|c|c|c|c|c|}
\hline Families & $\mathbf{N}_{\mathbf{G}}$ & $\mathbf{N}_{\mathbf{E}}$ & Families & $\mathbf{N}_{\mathbf{G}}$ & $\mathbf{N}_{\mathbf{E}}$ & Families & $\mathbf{N}_{\mathbf{G}}$ & $\mathbf{N}_{\mathbf{E}}$ \\
\hline Rubiaceae & 12 & 17 & Simaroubaceae & 2 & 3 & Caricaceae & 1 & 1 \\
\hline Euphorbiaceae & 9 & 12 & Vitaceae & 1 & 3 & Cecropiaceae & 1 & 1 \\
\hline Annonaceae & 9 & 11 & Acanthaceae & 2 & 2 & Comariopsidaceae & 1 & 1 \\
\hline Moraceae & 3 & 7 & Araliaceae & 2 & 2 & Lecythidaceae & 1 & 1 \\
\hline Anacadiaceae & 3 & 6 & Celastraceae & 1 & 2 & Leeaceae & 1 & 1 \\
\hline Clusiaceae & 3 & 5 & Myristicaceae & 1 & 2 & Opiliaceae & 1 & 1 \\
\hline Meliaceae & 4 & 5 & Myrtaceae & 2 & 2 & Passifloraceae & 1 & 1 \\
\hline Sapotaceae & 3 & 5 & Ochnaceae & 2 & 2 & Peripiocaceae & 1 & 1 \\
\hline Rutaceae & 3 & 4 & Olacaceae & 1 & 2 & Polygalaceae & 1 & 1 \\
\hline Apocynaceae & 2 & 3 & Thymeliaceae & 2 & 2 & Rhamnaceae & 1 & 1 \\
\hline
\end{tabular}

$\mathbf{N}_{\mathbf{G}}$ : Genera number; $\quad \mathbf{N}_{\mathbf{E}}$ : Species number.

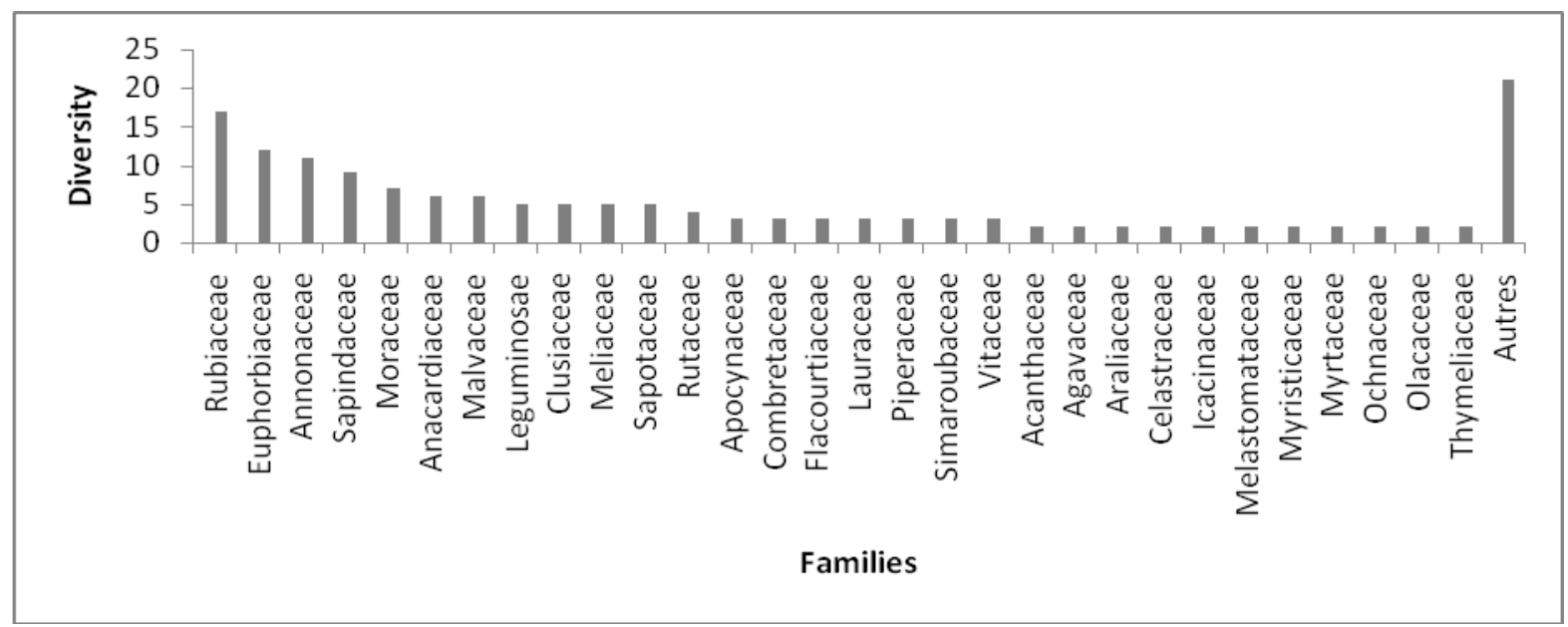

Fig. 3: Specific diversity of the families counted in the Mount Kupe submontane forest. The numbers of recorded species are indicated for every family.

\section{Family level}

Fifty-one families were registered in the sampling, taking the Fabaceae, Caesalpiniaceae and Mimosaceae as a single family (Leguminosae). The families with a higher relative dominance were Meliaceae, Euphorbiaceae, Burseraceae, Malvaceae, Clusiaceae, Rubiaceae, Olacaceae, Myristicaceae, Moraceae and Apocynaceae. Together, they represented $71.75 \%$ of the total basal area. From the relative density point of view, the ten most abundant families were Meliaceae, Rubiaceae,
Burseraceae, Menispermaceae, Malvaceae, Euphorbiaceae, Clusiaceae, Olacaceae, Anacardiaceae and Moraceae. The densities of Meliaceae, Rubiaceae, Burseraceae, Menispermaceae and Malvaceae were $>9 \%$ while those of Euphorbiaceae, Clusiaceae, Olacaceae and Anacardiaceae reached at least $7 \%$. The Rubiaceae accounted for $10.89 \%$ of all the species.

The Meliaceae, Rubiaceae, Burseraceae and Moraceae were the most abundant with $50.93 \%$ of individuals censused in the sample. The relative diversity of 
Rubiaceae (17 species) represents $10.89 \%$ of the total diversity of the sample. Twenty one families were represented by only one species, eleven by two species, seven by three species, one by four species and four by five species. The ten most important families for each of these relative parametres and the FIV are shown in Table 2. The values of the different parametres of these ten families with the highest family importance values (FIV) are presented in Fig. 4. The complete results for each of the families are given in Appendix 2.

Table 2. Families with the highest values of relative dominance, relative density, relative diversity and FIV in decreasing order.

\begin{tabular}{|c|c|c|c|c|c|c|c|}
\hline Relative dominance & {$\left[\begin{array}{ll}x & 100\end{array}\right]$} & $\begin{array}{l}\text { Relative } \\
\text { Density }\end{array}$ & {$\left[\begin{array}{ll}x & 100\end{array}\right]$} & Relative diversity & {$\left[\begin{array}{ll}x & 100\end{array}\right]$} & FIV & {$\left[\begin{array}{ll}\mathbf{x} & 300\end{array}\right]$} \\
\hline Euphorbiaceae & 14.78 & Rubiaceae & 13.70 & Euphorbiaceae & 7.69 & Rubiaceae & 32.40 \\
\hline Malvaceae & 10.61 & Menispermaceae & 9.96 & Sapindaceae & 5.69 & Malvaceae & 23.55 \\
\hline Clusiaceae & 9.65 & Malvaceae & 9.09 & Moraceae & 4.48 & Burseraceae & 21.25 \\
\hline Rubiaceae & 7.81 & Euphorbiaceae & 8.47 & Anacardiaceae & 3.85 & Clusiaceae & 20.13 \\
\hline Moraceae & 6.40 & Anacardiaceae & 7.26 & Clusiaceae & 3.21 & Sapotaceae & 14.29 \\
\hline Apocynaceae & 5.38 & Moraceae & 6.36 & Meliaceae & 3.21 & Menispermaceae & 13.78 \\
\hline
\end{tabular}

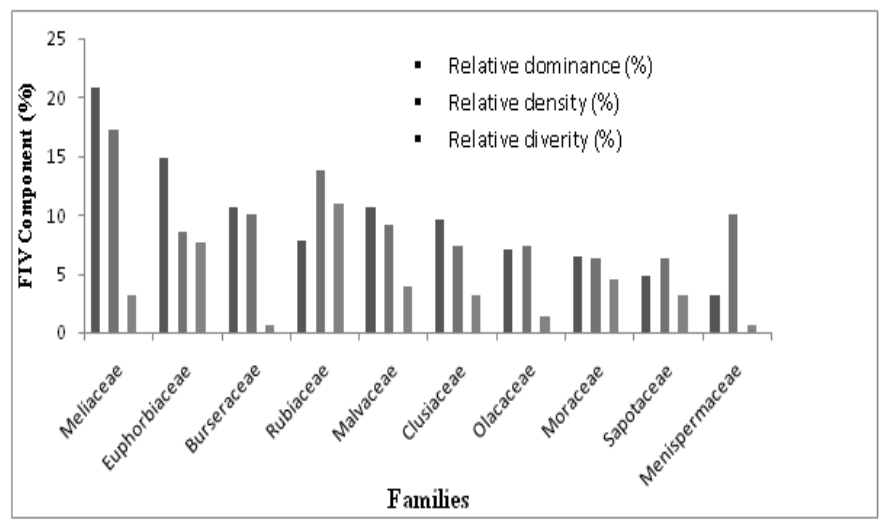

Fig. 4: Relative dominance, relative density and relative diversity of the ten most important families in FIV of the sample in 1 ha of the Mount Kupe submontane forest.

When we compared the FIV and the three relative values of the ten most important families, only the Clusiaceae, Euphorbiaceae, Malvaceae, Meliaceae, Moraceae and Rubiaceae came among the first ten families for all these parametres. The Menispermaceae had a higher dominance while the Burseraceae had both a higher dominance and density; they were both represented by only one species each (Penianthus longifolius and Santiria trimera respectively). From the family importance value point of view, the Meliaceae were the most abundant with an FIV of $41.22 \%$. They came first in relative density and dominance, and were $10^{\text {th }}$ in relative diversity. The Menispermaceae were $11^{\text {th }}$ in FIV due to their low relative diversities. The Moraceae were $5^{\text {th }}$ in relative diversity but dropped to the $7^{\text {th }}$ position in FIV because of their low relative dominance and density. The Euphorbiaceae were $6^{\text {th }}$ in relative density but, rose to the $3^{\text {th }}$ position in FIV as a result of their higher relative dominance and diversity. The Leguminosae were $8^{\text {th }}$ in relative diversity and $11^{\text {th }}$ in relative dominance but, dropped to the $14^{\text {th }}$ position in FIV because of their low relative density. The Sapindaceae, were $4^{\text {th }}$ in relative diversity but did not come among the first ten in FIV value. They occupied the $13^{\text {th }}$ position in FIV as a result of their low relative dominance and density.

\section{Specific level}

One hundred and fifty-six species were censused in an area of 1ha. The ten most abundant species for each of the parameter frequency, density and dominance were regrouped in Table 3. The complete result for each species is given in Appendix 3. The values of each of these parameters and the highest IVI (Importance Value Index) are represented in Fig. 5. Seven species representing $4.49 \%$ dominated the submontane forest and accounted for $34.30 \%$ of all the species censesed. A large number of species representing $69.23 \%$ was represented by six individuals; seventeen species were represented by two individuals; seventy species constituting $44.87 \%$ of total species censused were represented by one individual. From the point of view of dominance, Santiria trimera was $1^{\text {st }}$ in relative dominance, but drops to the $4^{\text {th }}$ position in relative density, while Penianthus longifolius which was $12^{\text {th }}$ in relative dominance and was $1^{\text {st }}$ in relative density. The species Carapa procera was $2^{\text {nd }}$ in relative dominance, but, dropped to the $16^{\text {th }}$ position in relative density. Pycnanthus angolensis was $4^{\text {th }}$ in relative dominance but, found itself in the $21^{\text {th }}$ position in relative density. Cola acuminata was $2^{\text {th }}$ in 
relative frequency but, was $6^{\text {th }}$ in relative density and $7^{\text {th }}$ in relative dominance. A small propoertion (5.13\%) of species accounted for $58.15 \%$ in relative dominance. The species Santiria trimera, Carapa procera, Strombosia pustulata, Pycnanthus angolensis, Turraeanthus africanus, Macaranga occidentalis, Cola acuminata and Drypetes leonensis had a relative dominance $>5 \%$. Attaining a higher dominance was restricted possibly by a high number of small individual or by a restricted number of large individual. The species Santiria trimera was $1^{\text {st }}$ in IVI due to their high values in relative dominance and frequency. The species/area cumulative curve of this submontane forest is shown in Fig. 6. The shape of the curve is an indication that it is possible to determine a satisfactory sample on a 1ha plot on the Mount Kupe submontane forest. This curve shows a large specific richness of the forest studied.

Table 3. Species with the highest values of relative frequency, relative density, relative dominance and IVI in decreasing order.

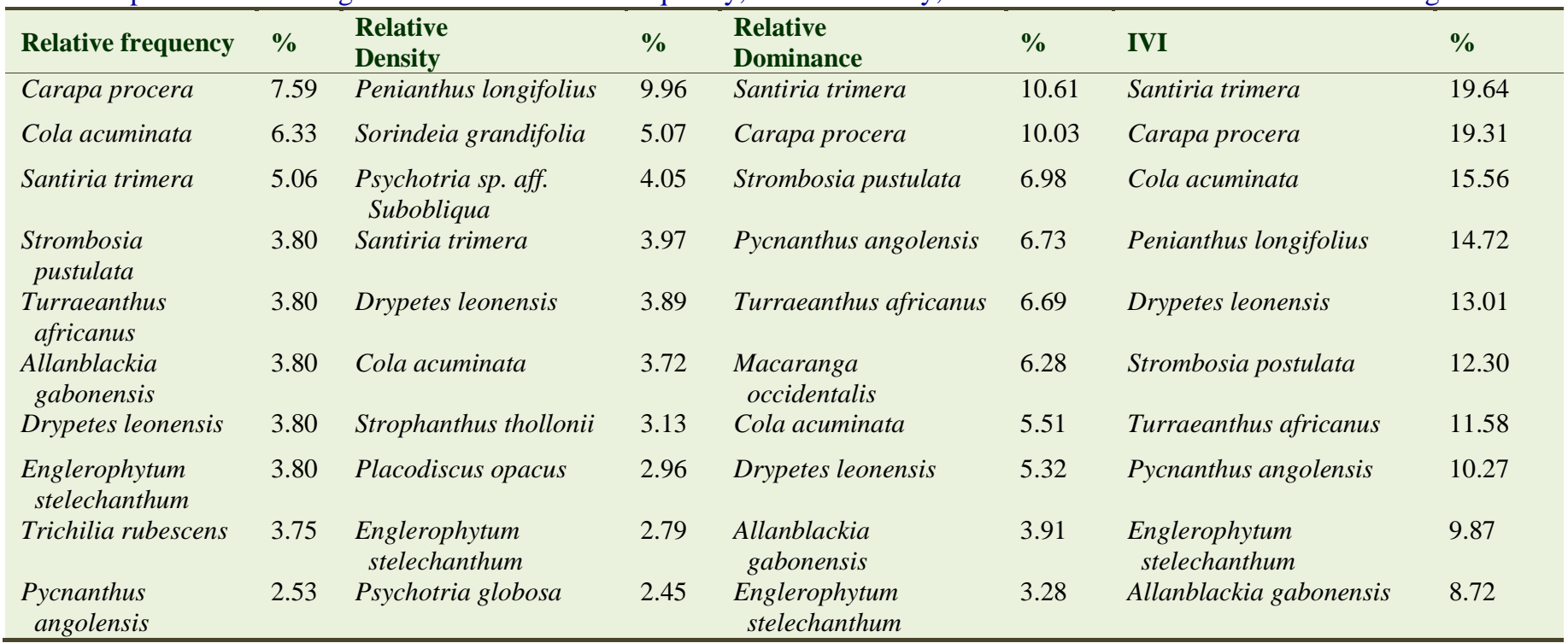

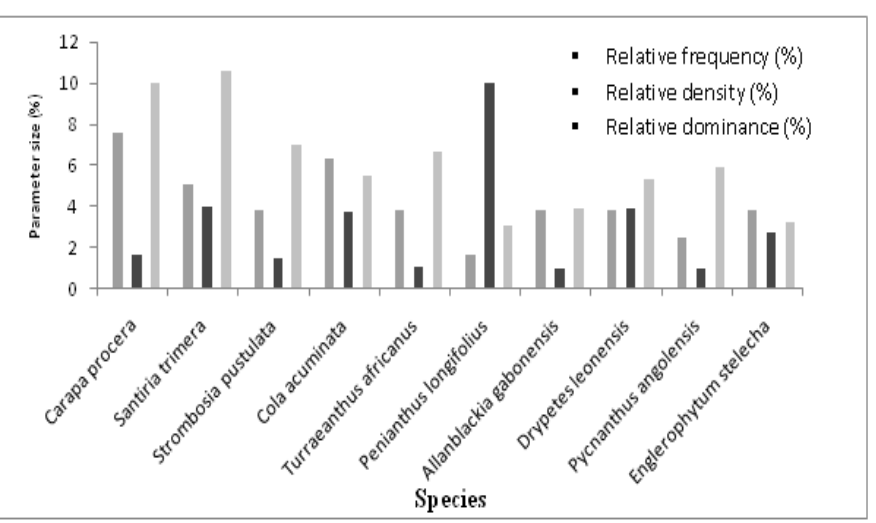

Fig. 5: Relative frequency, relative density and relative dominance of the ten most important species in IVI for 1 ha of the Mount Kupe submontane forest.

According to the phytogeographical affinity (Schnell, 1970; White, 1983; Senterre, 2005), the species of this submontane forest can subdivided into eight different groups of distribution: G (33.55), BG (18.06), At (17.42), CG (16.77), Ca (9.58), Aam (1.94), Am (1.29), Pal (1.29). $33.55 \%$ species are widely distributed in the GuineoCongolese region in both of the major sub-regional centers (upper and lower Guineo-Congolese). $18.06 \%$ of the species are lower Guinean; $17.42 \%$ are distributed in tropical Africa; $16.77 \%$ are Centro-Guineo-Congolese; 9.68\% are indicated in Cameroon exclusively. Many other species are shared by many distant domains: Aam (1.94\%), Am (1.29\%) and Pal (1.29\%), thus, their populations are discontinuous. The species with wide phytogeographical distribution are few, those of transition are relatively numerous and the Guinean species are very well represented. The altitudinal variance of species is an important aspect of the Mount Kupe submontane forest that distinguishes it from the lowland forest (Appendix 1). It was found that the distribution of species according to the highland elevation patterns (Senterre, 2005; Noumi, 1998, 2012, 2013) is as follows: Lower and middle altitude floor (Bm and $\mathrm{Bm}+\mathrm{Sm})(33.97 \%)$, sub-mountain floor $(\mathrm{Sm}$ and $\mathrm{Sm}+\mathrm{Mi})(51.92 \%)$, lower mountain or humid mountain floor (Mi) $(12.18 \%)$, species of wide spectre (1.29\%). Details are shown in Appendix 4. The combination of geographical and elevation parametres to be determined should be such that it allows the redistribution of the species in different chorological areas (Schnell, 1970) throughout the world. 


\section{Discussion}

\section{Floristic composition - Family level}

In the area sampled, more than $50.93 \%$ of all individuals were represented by four families. According to Rabevohitra et al. (1996) four, five or six families represent always more than $50 \%$ of total trees in the littoral forest along Madagascar's coast. Table 4 shows that in the Mount Kupe submontane forest and in the samples from other submontane and montane forests in Cameroon, Euphorbiaceae, Meliaceae and Rubiaceae are frequently classed among the ten most abundant families. The Menispermaceae seemed to be the only numerically abundant family in the Mount Kupe submontane forest that do not occur in the first ten positions in lowland forests in Cameroon but, in submontane and montane forests. Family composition in lowland forests of the tropics tends to be similar (Gentry, 1988; Noumi, 2012, 2013). They listed eleven families (Annonaceeae, Arecaceae, Bignoniaceae, Euphorbiaceae, Lauraceae, Leguminosae, Meliaceae, Moraceae, Myristicaceae, Rubiaceae and Sapotaceae) that contribute to half of the species' richness in a 1ha sampling plot in lowland Neotropical forests. At least eight of these families are always among the ten richest species in Africa and Asia as well. This is not the case with the Mount Kupe submontane forest. Only four families (Meliaceae, Rubiaceae, Burseraceae and Menispermaceae) contribute to half of the species' richness in a 1 ha sampling plot.

Table 4. The ten most abundant families in the Mount Kupe submontane forest compared to three Cameroonian highland forests.

\begin{tabular}{llll}
\hline $\begin{array}{l}\text { Kala forest } \\
\text { (Madiapevo, 2008) }\end{array}$ & $\begin{array}{l}\text { Kouoghap sacrad forest } \\
\text { (Noumi, 2012) }\end{array}$ & $\begin{array}{l}\text { Manengouba forest } \\
\text { (Noumi, 2013) }\end{array}$ & $\begin{array}{l}\text { Kupe submontane forest } \\
\text { (Present study) }\end{array}$ \\
Alt. 1000-1156 m & Alt. 1400-1550 $\mathbf{~ m}$ & Alt. 2200-2396 $\mathbf{~ m}$ & Meliaceae \\
\hline Myristicaceae & Rubiaceae & Myrsinaceae & Rubiaceae \\
Clusiaceae & Meliaceae & Rubiaceae & Burseraceae \\
Leguminosae & Moraceae & Euphorbiaceae & Menispermaceae \\
Annonaceae & Bignoniaceae & Araliaceae & Malvaceae \\
Rubiaceae & Apocynaceae & Meliaceae & Euphorbiaceae \\
Malvaceae & Sapotaceae & Opiliaceae & Clusiaceae \\
Meliaceae & Leguminosae & Thymeliaceae & Olacaceae \\
Apocynaceae & Euphorbiaceae & Cyatheaceae & Mordiaceae \\
Burseraceae & Araliaceae & Rutaceae & Morae \\
Euphorbiaceae & Clusiaceae & Rosaceae & \\
\hline
\end{tabular}

Among the aforementioned families, the Meliaceae, Euphorbiaceae, Rubiaceae, Malvaceae, Clusiaceae and Moraceae were among the ten important families in relative diversity and FIV in the surface sampled here (Table 5). It is remarkable that in Cameroon, Leguminosae also seem to be abundant in the submontane forests than in the Neotropical and African lowland forests. In the Kouoghap Sacrad forest (Noumi, 2012) they are second in FIV (FIV: 32.63), while in the Kala forest (Madiapevo, 2008) they are first out of 40 families, with an FIV value of 31.00. Similar abundance of Leguminosae in Cameroon was recorded by Tagne (2007) during the inventory of 1.25ha surface area in the submontane forest of Messa hill in Yaounde. Similar results were not obtained in the Mount Kupe submontane forest where they occupied the fourteenth position out of 51 families with an FIV of 12.53 (Tchoua, 2013). The scarcity of Leguminosae in the Mount Kupe submontane forest is worth noting. The same observation was made in the 1ha sampling plot of the Manengouba highland forest (Noumi, 2013). It is remarkable that in the Cameroonian submontane forests, the Meliaceae seemed to be more abundant than in the
Neotropical and African lowland forests. In the Mount Kupe submontane forest it is first with an FIV accumulation value of 41.22; it is also first with an FIV of 33.38 in the Kouoghap Sacrad forest (Noumi, 2012); $8^{\text {th }}$ with an FIV of 17.83 in the Kala forest (Madiopevo, 2008); $5^{\text {th }}$ with an FIV of 17.26 in the Messa forest (Tagne, 2007); $5^{\text {th }}$ with an FIV of 16.06 in the Manengouba forest (Noumi, 2013); and also $5^{\text {th }}$ with an FIV of 18.70 in the Yapo forest (Corthay, 1996). The family composition of the Mount Kupe submontane forest tend to be similar to those of the lowland forest, but the relative abundance of the families of higher altitude - Araliaceae: $23^{\text {th }}$ with an FIV of 4.01; Agavaceae: $34^{\text {th }}$ with an FIV of 1.94; Rosaceae: $40^{\text {th }}$ with an FIV of1.33 makes a distinction between the Mount Kupe submontane forest and the lowland forests. On the other hand in Cameroon, the Rubiaceae are much more abundant and more species-rich in the highland forests (Tagne, 2007; Madiapevo, 2008; Noumi, 2012, 2013). In the Mount Kupe submontane forest, the Meliaceae are much more abundant, the Euphorbiaceae and Meliaceae are much more dominant, with the Rubiaceae and Euphorbiaceae being the most diversified. 
Table 5. Family importance value of 15 most abundant plant families in the Mount Kupe sub mountain forest and 4 other Cameroonian highland forests, and 5 lowland tropical forests as reported by D'Amico and Gautier (2000).

\begin{tabular}{|c|c|c|c|c|c|c|c|c|c|}
\hline \multicolumn{2}{|c|}{$\begin{array}{l}\text { Kupe forest (Cameroon) } \\
\text { Present study }\end{array}$} & \multicolumn{2}{|c|}{$\begin{array}{l}\text { Manengouba forest } \\
\text { (Cameroon) } \\
\text { Noumi (2013) }\end{array}$} & \multicolumn{2}{|c|}{$\begin{array}{l}\text { Kouoghap Sacrad } \\
\text { forest (Cameroon) } \\
\text { Noumi (2012) }\end{array}$} & \multicolumn{2}{|c|}{$\begin{array}{l}\text { Kala forest (Cameroon) } \\
\text { Madiapevo (2008) }\end{array}$} & \multicolumn{2}{|c|}{$\begin{array}{l}\text { Messa forest (Cameroon), } \\
\text { Tagne (2007) }\end{array}$} \\
\hline Families & FIV & Families & FIV & Families & FIV & Families & FIV & Families & FIV \\
\hline Meliaceae & 41.22 & Rubiaceae & 56.19 & Meliaceae & 33.38 & Leguminosae & 31.00 & Leguminosae & 47.60 \\
\hline Rubiaceae & 32.40 & Euphorbiaceae & 55.71 & Leguminosae & 32.63 & Clusiaceae & 27.90 & Malvaceae & 33.17 \\
\hline Euphorbiaceae & 30.94 & Araliaceae & 51.03 & Moraceae & 31.81 & Myristicacaeae & 26.80 & Moraceae & 28.93 \\
\hline Malvaceae & 23.55 & Myrsinaceae & 49.52 & Sapotaceae & 26.83 & Burseraceae & 21.77 & Euphorbiaceae & 26.11 \\
\hline Burseraceae & 21.25 & Meliaceae & 16.06 & Rubiaceae & 26.12 & Malvaceae & 21.41 & Meliaceae & 17.26 \\
\hline Clusiaceae & 20.13 & Moraceae & 8.33 & Bignoniaceae & 21.16 & Annonaceae & 18.24 & Apocynaceae & 13.90 \\
\hline Moraceae & 17.24 & Rutaceae & 7.95 & Apocynaceae & 19.49 & Rubiaceae & 17.96 & Myristicaceae & 12.59 \\
\hline Anacardiaceae & 15.57 & Cyatheaceae & 7.40 & Euphorbiaceae & 15.74 & Meliaceae & 17.83 & Ulmaceae & 12.26 \\
\hline Olacaceae & 15.53 & Opiliaceae & 6.66 & Verbenaceae & 12.51 & Euphorbiaceae & 15.78 & Caricaceae & 10.57 \\
\hline Sapotaceae & 14.29 & Sapindaceae & 6.19 & Annonaceae & 11.23 & Apocynaceae & 13.76 & Rubiaceae & 10.12 \\
\hline Menispermaceae & 13.78 & Thymeliaceae & 5.59 & Burseraceae & 9.65 & Irvingiaceae & 8.18 & Bombacaceae & 7.44 \\
\hline Annonaceae & 13.05 & Rosaceae & 5.14 & Malvaceae & 9.33 & Moraceae & 8.13 & Cecropiaceae & 7.38 \\
\hline Sapindaceae & 12.80 & Melianthaceae & 4.26 & Araliaceae & 7.70 & Cecropiaceae & 7.92 & Combretaceae & 7.37 \\
\hline Leguminosae & 12.53 & Asteraceae & 3.14 & Agavaceae & 6.83 & Flacourtiaceae & 7.43 & Lauraceae & 7.19 \\
\hline Apocynaceae & 12.14 & Alangiaceae & 3.10 & Clusiaceae & 6.66 & Sapotaceae & 7.38 & Olacaceae & 6.85 \\
\hline \multicolumn{2}{|l|}{$\begin{array}{l}\text { Yapo (Ivory Coast) } \\
\text { Corthay (1996) }\end{array}$} & \multicolumn{2}{|c|}{$\begin{array}{l}\text { Manongarivo (Madagascar) } \\
\text { D'Amigo and Gautier (2000) }\end{array}$} & \multicolumn{2}{|c|}{$\begin{array}{l}\text { Alto Parana } \\
\text { (Paraguay) Spichiger } \\
\text { et al. (1992) }\end{array}$} & \multicolumn{2}{|c|}{$\begin{array}{l}\text { Yasuni (Ecuador) Balslev } \\
\text { et al. (1987) }\end{array}$} & \multicolumn{2}{|c|}{$\begin{array}{l}\text { Jenera Herrera (Peru) } \\
\text { Spichiger et al. (1996) }\end{array}$} \\
\hline Families & FIV & Families & FIV & Families & FIV & Families & FIV & Families & FIV \\
\hline Sapotaceae & 34.15 & Clusiaceae & 40.78 & Meliaceae & 44.40 & Arecaceae & 55.66 & Leguminosae & 29.07 \\
\hline Leguminosae & 32.27 & Euphorbiaceae & 29.09 & Lauraceae & 42.40 & Moraceae & 36.48 & Sapotaceae & 28.22 \\
\hline Burseraceae & 24.83 & Myrtaceae & 27.17 & Sapotaceae & 39.40 & Leguminosae & 23.73 & Moraceae & 23.50 \\
\hline Euphorbiaceae & 18.88 & Rubiaceae & 21.23 & Leguminosae & 31.90 & Bombacaceae & 19.66 & Myristicaceae & 18.84 \\
\hline Meliaceae & 18.70 & Myristicaceae & 19.04 & Rutaceae & 25.40 & Myristicaceae & 19.59 & Lauraceae & 18.28 \\
\hline Malvaceae & 18.57 & Lauraceae & 16.32 & Moraceae & 20.40 & Rubiaceae & 14.73 & Chrysobalanaceae & 18.05 \\
\hline Ebenaceae & 15.49 & Burseraceae & 13.77 & Boraginaceae & 14.70 & Meliaceae & 11.62 & Lecythidaceae & 17.38 \\
\hline Clusiaceae & 14.85 & Sapotaceae & 10.48 & Arecaceae & 11.10 & Euphorbiaceae & 8.15 & Burseraceae & 11.84 \\
\hline Olacaceae & 13.51 & Erythroxylaceae & 9.51 & Annonaceae & 10.10 & Cecropiaceae & 7.86 & Annonaceae & 10.67 \\
\hline Chrysobalanaceae & 12.08 & Annonaceae & 9.37 & Bignoniaceae & 8.20 & Lecythidaceae & 7.54 & Arecaceae & 9.47 \\
\hline Flacourtiaceae & 11.91 & Sarcolaenaceae & 8.27 & Solanaceae & 4.60 & Lauraceae & 7.37 & Vochysiaceae & 9.43 \\
\hline Combretaceae & 8.75 & Asteraceae & 8.22 & Myrtaceae & 3.50 & Malvaceae & 6.72 & Humiraceae & 8.52 \\
\hline Lecythidaceae & 6.64 & Leguminosae & 7.71 & Sapindaceae & 3.20 & Flacourtiaceae & 6.18 & Cecropiaceae & 7.89 \\
\hline Irvingiaceae & 6.37 & Ebenaceae & 7.57 & Flacourtiaceae & 2.70 & Polygonaceae & 6.07 & Rubiaceae & 7.79 \\
\hline Scytopetalaceae & 6.35 & Arecaceae & 7.17 & Euphorbiaceae & 2.50 & Sapotaceae & 5.59 & Combretaceae & 7.50 \\
\hline
\end{tabular}

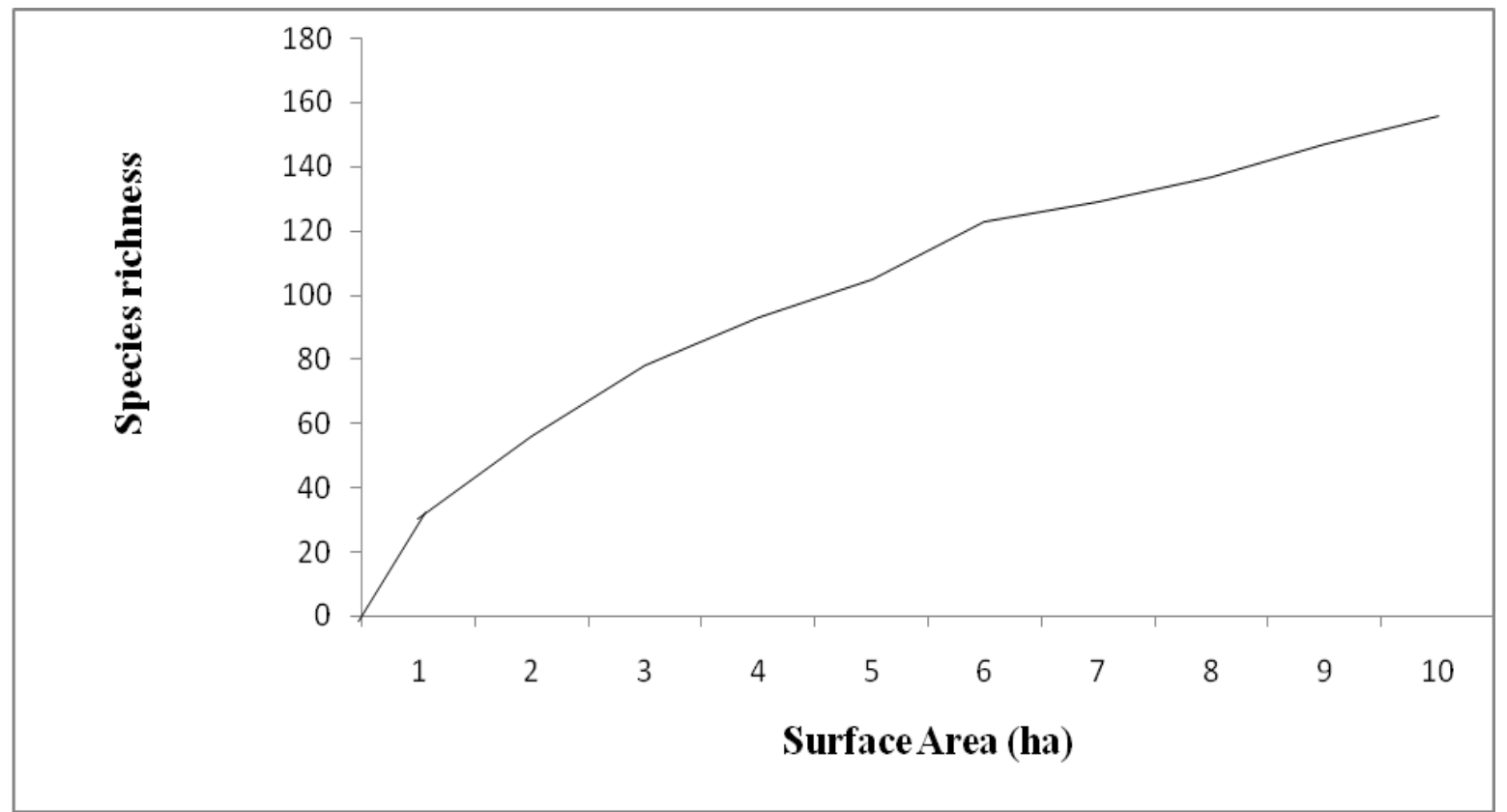

Fig. 6: Species/area cumulative curve of the 1 ha sampling plot in the Mount Kupe sub mountain forest (for ligneous flora with dbh $\geq 10 \mathrm{~cm}$ ). Each sub-unit is represented by a surface area of $40 \mathrm{~cm}$ by $25 \mathrm{~cm}$. 


\section{Specific level}

In this inventory, one hundred and fifty-six (156) pecies were met in a 1ha sampling plot. In the other Cameroonian highland forests, this number seems to fluctuate within a sampling area of 1 ha estimated by the same method (Kala, 178 species/ha; Messa, 151 species/ha; Kouoghap Sacrad forest, 79 species/ha; Manengouba, 40 species/ha). This variation is similar in other countries of tropical Africa ranging between 40 and 178 (Table 6). In Madagascar, it is 38 - 146 (Rabevohitra et al., 1996). In the Neotropical region, it is 228 in the
Amazonian forest of Ecuador (Balslev et al., 1987). Low values of diversity have been registered in Ivory Coast where Corthay (1996) found 76 and 77 species/ha in two plots of the classified forest of Yapo and in Alto Parana where Spichiger et al. (1992) found 60 species/ha. The Mount Kupe submontane forest (156 species/ha) is characterized by the highest value of the species number per hectare registered by different studies in the African, Malagasy and Neotropical forests. The selective conditions of the mesological factors in the submontane zone considerably increase the number of species contrary to those of the Manengouba highland.

Table 6. Number of species per/ha and Shannon diversity index of the Guinean - Congolese rainforests, in order of decreasing density.

\begin{tabular}{lllll}
\hline Name of the forest & Countries & Authors & $\begin{array}{l}\text { No. of } \\
\text { Species/ha }\end{array}$ & $\begin{array}{l}\text { Shannon's } \\
\text { Diversity } \\
\text { Index }\end{array}$ \\
\hline Kala forest & Cameroon & Madiapevo (2008) & 178 & 5.19 \\
Kupe forest & Cameroon & Tchoua (2013) & 156 & 5.86 \\
Messa forest & Cameroon & Tagne (2007) & 151 & 6.24 \\
Dja Biosphere Reserve forest & Cameroon & Sonké (1998) & 138 & 5.62 \\
Lopé forest & Gabon & White (1992) & 129 & 4.14 \\
Kouoghap Sacrad forest & Cameroon & Noumi (2012) & 79 & 4.83 \\
Yapo forest & Côte d'Ivoire & Corthay (1996) & 77 & 6.19 \\
Ngotto forest & République Centrafricaine & Lejoly (1995) & 58 & 5.30 \\
Cleistopholis patens and Ficus mucusoforest & Benin & Sokpon (1995) & 53 & 4.76 \\
Manengouba forest & Cameroon & Noumi (2013) & 40 & 3.98 \\
\hline
\end{tabular}

According to Rollet (1983), 50\% of individuals on average are represented by twenty species in the undisturbed lowland Amazonian forest of Venezuela. In the Mount Kupe submontane forest, half of all individuals are represented by only fourteen species. Similar values were found in the Messa forest (17 species) (Tagne, 2007); Kala forest (7 species) (Madiapevo, 2008); Kouoghap Sacrad forest (5 species); Manengouba forest (4 species) all in Cameroon (Noumi, 2012, 2013); and in the Manongarivo forest (11 species) were classed by D'Amico and Gautier, 2000). Only four of these species were classed among the ten most abundant families in terms of their FIV values as a result of their relative densities. The individuals/species ratio in the Mount Kupe sampling plot is 7.59 (Tchoua, 2013). Other studies in Cameroon, recorded values of 33.4 (Noumi, 2012); 19.13 (Noumi and Kitio, 2013); 10.57 (Madiapevo, 2008); and 8.03 (Tagne, 2007). Other ratios have been found for the tropical regions and Malagasy: 22.1 (Rabevohitra et al., 1996); 8.1 (D'Amico and Gautier, 2000); 7.96 and 8.42 (Corthay, 1996). A series of tha forest inventory samples in the Neotropics recorded the following values: 7.37 in Paraguay
(Spichiger et al., 1992); 2.79 in Ecuador (Balslev et al., 1987). The exaggerated gregariousness of some species in the Mount Kupe submontane forest is therefore brought to the fore from $1600 \mathrm{~m}$ of altitude.

The Shannon diversity index (ISH) (Shannon and Weaver, 1949) enables a good appreciation of the diversity on the different plots because it takes into account the number of species and the abundance in distribution. Its calculated values for different Guinean forests are between 4 and 6.5. The Mount Kupe formations presents a higher Shanon index value (IHS = 5.86), which shows a better diversified forest, with gregarious species (Table 6).

Mori et al. (1983) considered species found only once in the sample as rare. In the Kouoghap Sacrad forest of Western Cameroon, 32.5\% (Noumi, 2012) of species were rare, according to this definition. An inventory in the Messa forest (Tagne, 2007) recorded a value of $28 \%$. In this study, the percentage of species represented by only one individual (44.87\%) is higher than those found in the above mentioned studies and is close to the value 
found in Eastern Brazil 41.0\% (Mori et al., 1983), but is higher than 22\% (Spichiger et $a l, 1992$ ) as in the Alto Parana; 21.0\% (D'Amico and Gautier, 2000) in Manongarivo and 12.5\% (Madiapevo, 2008) in Kala.

The IVI of Santiria trimera, the species with the highest in the plot, is 19.64. This species is not present in the Manengouba highland vegetation (Noumi, 2013); the vegetation of Kouoghap Sacrad forest (Noumi, 2012), the Mount Kala submontane vegetation (Madiapevo, 2008), and the Messa hill (Tagne, 2007).

The floristic composition of the Mount Kupe submontane forest matches up, according to the parametres under consideration in this study, with some lowland forests. However, there are some discrepancies that could be explained by altitude. In the Mount Kupe submontane forest, as well as in other forests with an elevation above $1000 \mathrm{~m}$, the species (and other main ones) with the highest IVI is a submontane species: Santiria trimera, Burseraceae. (Syncepalum cerasiferum, Sapotaceae in the Kouoghap Sacrad forest; Allanblackia gabonensis, Clusiaceae in the Kala forest; Cylicomorpha solmsii, Caricaceae in the Messa forest; or a highland species: Macaranga occidentalis, Euphorbiaceae in the Manengouba highland forest. Furthermore, the presence of Alangiaceae, Araliaceae and Clusiaceae clearly corresponds to the typical submontane forest constituted by the Mount Kupe formation.

The phytogeographic affinities: According to White (1983) the Cameroonian submontane forests form an archipelago connected comfortably, from the floristic point of view, to the other African highland archipelagos. The phytogeographical affinities of the mountain species recorded here falls within many distribution patterns.

Size of plant species: $78.06 \%$ of total species are widely distributed in the Guinean-Congolese regional forest; among which are: Alangium chinense with a paleotropical distribution (Jacques-Felix, 1970). Prunus africana is the species distributed throughout three African archipelagos (Cameroonian Afro-highland archipelago, East and South African highland archipelagos). Allophylus bullatus is endemic to the Cameroonian highland archipelago.

The altitudinal affinities: Comparing floristic composition of the Mount Kupe submontane forest and other highland rainforests sampled in Cameroon (Letouzey, 1985), 59 (37.82\%) species are shared with submontane vegetation; $31(19.87 \%)$ species in the lowland vegetation and submontane forests; 22 (14.10\%) species in the lowland vegetation; $22(14.10 \%)$ species in the submontane and lower montane vegetation; and 19 $(12.18 \%)$ species in the lower montane vegetation. They are: (Alangium chinense, Cissus amoena, Crotonogyne preussii, Cryptolepis sanguinolenta, Cyathea camerouniana, Dracaena sp. aff. phrynioides, Erythrococca anomala, kigelia africana, Monodora myristica, Octoknema genovefae, Peperomia pallucida, Piper umbellatum, Psychotria gabonica, Psychotria succulenta, Rutidea glabra, Salacia loloensis, Sorindeia winkleri, Tarrena eketensis, Urera repens); 2 (1.29\%) species have a wide distribution. A total of 1184 individuals belonging to 156 species, 114 genera and 51 families were recorded. They reached a total basal area of $151.44 \mathrm{~m}^{2} / \mathrm{ha}$.

\section{Conclusion}

The present work is spread out upon the whole submontane area covered by the Mount Kupe forest. There is a very marked qualitative difference judging from the abundance of the Leguminosae family in the lowland forests and rarity in the Mount Kupe submontane forest. The Leguminosae families which dominate in the lowland forests do not occur among the ten most abundant families in terms of their FIV; they rather come in the $14^{\text {th }}$ position. Here, the Rubiaceae families mark the submontane storey by their diversity and their second position in terms of their FIV.

From the quantitative point of view, the Penianthus longifolius species are very rare in the lowland forests but mark the Mount Kupe submontane forest by its abundance and $4^{\text {th }}$ position in IVI. In conclusion, the Mount Kupe submontane forest distinguishes itself substantially from the lowland forests. Floristic affinities of the species show that more than twenty-five species are orophytes amongst which some are widely distributed in the Guinean-Congolese region, whereas others are shared with the East and South African archipelagos.

\section{Conflict of interest statement}

Authors declare that they have no conflict of interest.

\section{References}

Balslev, H.J., Ollgaard, L.B., Holm-Nielsen, 1987. Composition and structure of adjacent unflooded and floodplain forest in Amazonian Ecuador. Opera Bot. 92, $37-57$. 
Cheek, M., Pollard, B.J., Darbyshire, L., Onana, J.M., Wild, C., 2004. The plants of Kupe, Nwanenguba and the Bakossi Mountains, Cameroon: A conservation check list. Kew Plants People Possibilités. 484p.

Colinveaix, P., 1986. Ecology. Wiley \& Sons, New York, Chichester. Brisbane, Totonto, Singapour. 725p.

Corthay, R., 1996. Floristic analysis of the Yapo rainforest (Ivory Coast). Diploma thesis, University of Geneva.

Curtis, J.T., Mc Intosh, R.P., 1950. The interrelation of certains analytic and synthetic phytosociological characters. Ecology. 31(3), 434-455.

Dagnelie, P., 1981. Statistic Theory and Methods. Vol. 2. The Gembloux Agronomic Press, Gembloux. 463p.

D'Amico, C., Gautier, L., 2000. Inventory of a 1 ha lowland rainforest plot in Manongarivo (NW Madagascar). Candollea. 55, 319-340.

Devineau, J.L., 1984. Structure and dynamics of sometropophile forests of west Africa (Ivory Coast) MAB savanna Program, 5 : University of Abidjan. 219p.

Doucet, J.C., 1996. Natural Regeneration in the UER Bee Forest. The Gembloux Agronomic University Faculty, Gabon. 127 p.

Gentry, A.H., 1988. Changes in plant community diversity and floristic composition on environmental and geographical gradients. Ann. Missouri Bot. Gard. 75, 1-34.

Geze, B., 1943. Physical Geography and Geology of Western Cameroon. M.N.H.N. Memory Paris, T.XVII. 320p..

Gounot, M., 1969. Quantitative Method of Vegetation Survey. Masson and Company, Paris. 314p.

Jacques-Félix, H., 1970. Ombellales. Flora of Cameroon 10. MESRES, Yaoundé, Cameroon. 108p.

Lamilen, B.D., 1989. Contribution at the study of anorogenic complex of Mount Kupe : an example of incomplete petrology-geochemistry alcalin serie. Doctorate thesis, University of Yaoundé. 169p.

Lamilen, B.D., Moundi, A., Moupou, M., Minyem, D., 1998. Control of socle in the morphology of anorogenic massive of Kupe (Cameroon line). In: Geosciences of Cameroon. (Eds.: Vicat, J.P., Bilong, P.). Coll. GEO CAM. pp.191196.

Lebrun, J., Gilbert, G., 1954. An Ecology Classification of the Belgian Congo Forests. Publ. I.N.E.A.C. Series- Science 63. 101p.

Lebrun, J.P.S., Stork, A.L., 1991, 1992, 1995, 1997. Induction of the flowering plants of tropical Africa. 4 Volumes. Editions of the Cconservatories and Garden Botanies of the City of Geneva, Switzerland.

Legendre, L., Legendre, P., 1984. Numeric Ecology: The Numerous Treatment of Ecologic Data. Tome 1. Masson, Paris. 260p.

Lejoly, J., 1995. Using of the transect method in the survey of biodiversity in the conservation zone of the Ngotto forest Centrafrican Republic. Technical Report. Ecofac, AgrecoCTFT Project. 114p.

Letouzey, R., 1968. Phytogeographic Study of Cameroon. (Ed.: Lechevalier, P.). Paris. 511p.

Letouzey, R., 1985. Note of the phytogeographic map of
Cameroon at 1/500 000. I; R.A. Yaoundé. 240p.

Mandango, M.A., 1982. Flora and vegetation of the Zaïre island river in the sub-region of Tshopo (high Zaïre). Doctorate thesis, University of Kisangani. 425p.

Madiapevo, S.N., 2008. Study of the diversity and the structure of the woody plant of the submontane forest of the Kala Mount $(1156 \mathrm{~m})$, region of Yaoundé. Memory of DEA thesis, University of Yaoundé 1.65p.

Melingui, A., Gwanfogbe, M., Ngoughia, J., Moukam, J., 1989. Geography of Cameroon. New Edition-CEPER Yaoundé. 120p.

Mori, S.A., Boom, B.M., Carvalho, A.M., and Dos Santos, T.S., 1983. Ecological importance of Myrtaceae in an Eastern Brazilian wet forest. Biotrop. 15, 68-70.

Normand, M.D., 1965. Identification of the trees and the woods of the main forest species in the Centrafican Republic. C.T.F.T. Nogent-sur-Marne. 78p.

Noumi, E., 1998. The transition forest of Garcinia spp. of the Nkolobot hills (Region of Yaoundé, Cameroon). Belg. Jour. Bot. 1305(2), 198-220.

Noumi, E., 2012. Ligneous flora diversity of a submontane forest of west Cameroon, the Kouoghap sacral forest of the village Batoufam. J. Ecol. Nat. Env. 4(1), 8-28.

Noumi, E., 2013. Floristic inventory of woody species in the Manengouba mountain forest, Cameroon. J. Biol. Life Sci. 4, 282-309.

Pielou, E.C., 1966. Species diversity and pattern diversity in study of ecological succession. J. Theor. Biol. 10, 370383.

Rabevohitra, R., Lowry II, P.P., Randrianjafy, H., Shatz, G.E., Razafindrianilana, N., 1996. Assessment of plant diversity and conservation importance of East Coast low elevation Malagasy rain forests. Report on the Project: National Center of Research Applied to the Farming Development, Madagascar. Department of Forest and Piscicoles Research, Madagascar. Biodiversity Support Program, Missouri Botanical Garden, St Louos.

Raunkiaer, R., 1934. The Life Form of Plants and Statistical Plant Geography. Clarendron Press, Oxford. 632p.

Rollet, B., 1983. The natural regeneration in the openings. A general process of the dynamics of the humid tropical forests. Woods Forests Trop. 201, 3-34.

Schnell, R., 1970. Introduction to the Phytogeography of the Tropical Countries: The General Problems 1. GauthierVillars, Paris. 499p.

Senterre, B., Nguema, N., 2001. The diversity of ligneous of the Nsork forest (Equatorial Guinea). Syst. Geogr. Pi 71, 837-846.

Senterre, B., 2005. Methodological Research for the Typology of the Vegetation and the Phytogeography of the Tropical Africa Rainforests. Doctorate thesis in Agro. Scien. Biol. Engineering. Free University of Brussels. 347p.

Shannon, C.E., Weaver, W., 1949. The Mathematical Theory of Communication. Urbana Univ. Press, Illinois. pp.117127.

Sokpon, N.S., 1995. Ecological Research on the Moist Semideciduous Forest of the Cleistopholis patens and Ficus 
тисиso Forest in the South-East of Benin: Plant Groupings, Natural Regeneration and Fall of the Litter. Doctorate thesis, Free University of Brussels. 350p.

Sonké, B., 1998. Floristic and structure studies of the Dja reserve of fauna forests (Cameroon). Doctorate thesis. Free University of Brussels. 267p.

Spichiger, R., Bertoni, B.S., Loizeau, P.A., 1992. The forest of Alto Parana Candollea. 47, 219-250.

Spichiger, R., Loizeau, P.A., Latou, C., Barriera, G., 1996. Tree species richness of South-Western Amazonian forest (Janero Herrera, Peru, $73^{0} 40^{\prime} \mathrm{W} / 4^{0} 544 \mathrm{~S}$ ). Candollea. 51, 559-577.

Suchel, J.B., 1987. The climate of Cameroon. Doctorate thesis, University of St-Etienne 2. 1185p.

Tagne, T.G.A., 2007. Floristic and structural study of the ligneous flora of the submontane forest of the Messa hill (Yaoundé). Memory of DEA thesis, University of Yaoundé 1. 66p.

Tchiengué, B., 2004. Floristic and Ecological Study of the Vegetation of One Massive of the Cameroon Line: the Kupe Mount. Doctorate thesis, University of Yaoundé 1. 238p.

Tchoua, T.J.M., 2013. Phytogeographical Study of the Mount Kupe Submontane Storey (Moungo-Cameroon). Memory of Master thesis, University of Yaoundé 1. 50p.
Tchoumi, N.F., 2004. Floristic and Structural Study of the Ligneous Species of the Manengouba Massive Highlanders Forests (East side). Memory of DEA thesis, University of Yaoundé 1.63p.

Van Reeth, L., 1997. Analysis of the Biodiversity of the Ligneous Flora in the National Park of Monte Alén in Equatorial Guinea. End of Study Work, Lab. Syst. Bot. Phytosociol., Free University of Brussels. 119p.

Vivien, J., Faure, J.J., 1982. Trees in dense forest of Central Africa. ACCT, Paris. 565p.

White, F., 1983. The Vegetation of Africa. A Descriptive Memory to Accompany the UNESCO/AETFAT/UNSO Vegetation Map of Africa. Natural Resources Research 20, UNESCO, Paris. 356p.

White, J.T.L., 1992. Vegetation History and Logging Disturbance: Effects on Rain Forest Mammals in the Lopé Reserve, Gabon (with Special Emphasis on Elephants and Apes). Ph.D. thesis, University of Edinburg, Edinburg. 250p.

Yahmed, D.B., Houstin, N., 2006. Atlas of Africa, Cameroon. Jeune Afrique Editions, Paris. 135p.

\section{List of Appendices}

Appendix 1. Floristic list of the Mount Kupe submontane forest, with the number of individual by class average of diameter encountered on 10 sampling plots. TP : Phytogeographic type; TB : Biologic type; TF : Leaf dimension type; TD : Spore type; TH : Steep type.

Appendix 2. The 51 families with their values of relative dominance, relative density, relative diversity and FIV in decreasing order.

Appendix 3. The 156 species with their basal areas; their relative frequency, relative density, relative dominance and IVI in decreasing order.

Appendix 4. Rough and balanced spectres of phytogéographic type (TP), biologic type (TB), leaf types (TF), spore type (TD) and steep type (TH) of the species recorded in Mount Kupe submontane forest. 
Appendix 1. Floristic list of the Mount Kupe submontane forest, with the number of individual by class average of diameter encountered on 10 sampling plots. TP : Phytogeographic type; TB : Biologic type; TF : Leaf dimension type; TD : Spore type; TH : Steep type.

\begin{tabular}{|c|c|c|c|c|c|c|c|c|c|c|c|c|c|c|c|c|c|c|c|c|c|c|c|c|c|c|c|c|c|c|c|c|c|c|c|c|}
\hline \multirow[b]{2}{*}{ E } & \multirow[b]{2}{*}{ 电 } & \multirow[b]{2}{*}{ 酉 } & \multirow[b]{2}{*}{ 是 } & \multirow[b]{2}{*}{$\underline{ت}$} & \multirow[b]{2}{*}{ 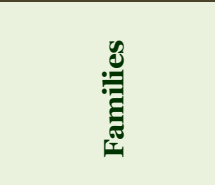 } & \multirow[b]{2}{*}{ 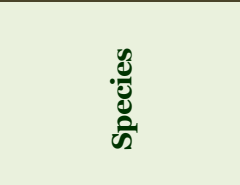 } & \multicolumn{10}{|c|}{ Plots } & \multicolumn{20}{|c|}{ Average class of diameter } \\
\hline & & & & & & & 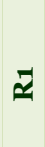 & $\stackrel{\vartheta}{\varkappa}$ & $\ddot{\varkappa}$ & $\approx$ & 2 & $\approx$ & 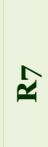 & $\stackrel{\infty}{\varkappa}$ & वे & $\stackrel{0}{2}$ & 12 & ลิ & $\stackrel{10}{0}$ & $\stackrel{10}{+}$ & $\frac{10}{6}$ & $\stackrel{10}{8}$ & $\stackrel{10}{1}$ & $\stackrel{0}{\infty}$ & & है & $\stackrel{20}{0}$ & $\stackrel{10}{7}$ & ลี่ & ติ & $\frac{1}{10}$ & ลี & $\stackrel{10}{0}$ & & $\frac{10}{\infty}$ & $\sum_{\substack{0 \\
:}}^{0}$ \\
\hline At & $\mathrm{NnPh}$ & Micro & Sarco & sm & Leguminosae & $\begin{array}{l}\text { Adenocarpus mannï } \\
\text { (Hook.f.) Hook. f. }\end{array}$ & & & & & & $r$ & & & & & -1 & & & & & & & & & & & & & & & & & & & 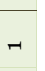 \\
\hline Pal & $\mathrm{McPh}$ & Macro & Baro & $\mathrm{mi}$ & Alangiaceae & $\begin{array}{l}\text { Alangium chinense } \\
\text { (Lour.) Harms }\end{array}$ & & - & & & & & & & & & & & & & & & & & & & & & & - & & & & & & - \\
\hline GC & $\mathrm{MsPh}$ & Méso & Ballo & $\begin{array}{l}\mathrm{bm}+ \\
\mathrm{sm}\end{array}$ & Euphorbiaceae & $\begin{array}{l}\text { Alchornea floribunda } \\
\text { Müll. Arg. }\end{array}$ & $\infty$ & & & $r$ & & $\wedge$ & & & & & 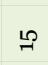 & -7 & & & & & & & & & & & & & & & & & & $\stackrel{0}{\sim}$ \\
\hline CG & $\mathrm{McPh}$ & Micro & Sarco & $\begin{array}{l}\mathrm{bm}+ \\
\mathrm{sm}\end{array}$ & $\begin{array}{l}\text { Euphorbiaceae } \\
\text { Clusiaceae }\end{array}$ & $\begin{array}{l}\text { Alchornea hirtella } \\
\text { Benth.fa.glabata } \\
\text { (Müll. Arg.) Pax \& } \\
\text { K. Hoffm. } \\
\text { Allanblackia } \\
\text { floribunda Oliv. }\end{array}$ & $\wedge$ & N & $\infty$ & & & & & & & & -7 & -1 & & $\infty$ & & & $\infty$ & 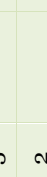 & & a & -1 & & & & & & & & & $\frac{7}{N}$ \\
\hline G & $\mathrm{McPh}$ & Méso & Scléro & sm & Sapindaceae & $\begin{array}{l}\text { Allophylus africanus } \\
\text { P. Beauv. } \\
\text { Var.africanus }\end{array}$ & & & & & & - & & & & & & -1 & & & & & & & & & & & & & & & & & & \\
\hline Ca & $\mathrm{McPh}$ & Méso & Scléro & $\begin{array}{l}\mathrm{sm}+ \\
\mathrm{mi}\end{array}$ & Sapindaceae & $\begin{array}{l}\text { Allophylus bullatus } \\
\text { Radlk. }\end{array}$ & & & & & & & & & $r$ & N & a & $r$ & & & & & & & & & & & & & & & & & & $\infty$ \\
\hline BG & $\mathrm{McPh}$ & Méso & Scléro & $\mathrm{sm}$ & Sapindaceae & $\begin{array}{l}\text { Allophylus } \\
\text { grandifolius (Baker) } \\
\text { Radlk. }\end{array}$ & & & & & -7 & & & & & & -1 & & & & & & & & & & & & & & & & & & & 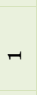 \\
\hline G & $\mathrm{MsPh}$ & Méso & Sarco & $\begin{array}{l}\mathrm{bm}+ \\
\mathrm{sm}\end{array}$ & Sapotaceae & $\begin{array}{l}\text { Aningeria robusta } \\
\text { (A. Chev.) Aubrév. \& } \\
\text { Pellegr. }\end{array}$ & & -7 & & & & & & & & & & -1 & & & & & & & & & & & & & & & & & & 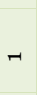 \\
\hline GC & $\mathrm{MsPh}$ & Macro & Sarco & $\mathrm{bm}$ & Annonaceae & $\begin{array}{l}\text { Anonidium mannii } \\
\text { (Oliv.) Engl.\& Diels }\end{array}$ & & & & a & & & & & & & & $r$ & & & & & & - & - & & & & & & & & & & & N \\
\hline At & $\mathrm{MgPh}$ & Macro & Ballo & $\mathrm{bm}$ & Moraceae & $\begin{array}{l}\text { Antiaris toxicaria } \\
\text { var.welwitschii } \\
\text { (Engl.)C.C.Berg. }\end{array}$ & & & & & -1 & & & & & & & & & & & & & & & & $\pi$ & & & & & & & & & - \\
\hline GC & $\mathrm{McPh}$ & Méso & Sarco & sm & Euphorbiaceae & $\begin{array}{l}\text { Antidesma } \\
\text { laciniantum } \\
\text { Müll.Arg. var. } \\
\text { laciniantum }\end{array}$ & & & & & -1 & & & & & & & & & 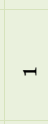 & & & & & & & & & & & & & & & & -1 \\
\hline CG & $\mathrm{McPh}$ & Méso & Sarco & $\mathrm{sm}$ & Euphorbiaceae & $\begin{array}{l}\text { Antidesma } \\
\text { vogelianum Müll. } \\
\text { Arg. }\end{array}$ & & & & & & N & & & & & N & & & & & & & & & & & & & & & & & & & a \\
\hline CG & Phgr & Méso & Sarco & sm & Annonaceae & $\begin{array}{l}\text { Artabotrys } \\
\text { congolensis De Wild } \\
\text { \& T. Durand }\end{array}$ & & & & & $r$ & & & & & & -1 & & & & & & & & & & & & & & & & & & & 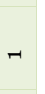 \\
\hline BG & $\mathrm{McPh}$ & Micro & Sarco & sm & Passifloraceae & $\begin{array}{l}\text { Barteria solida } \\
\text { Breteler }\end{array}$ & & & N & $r$ & & & & & & & $\infty$ & & & & & & & & & & & & & & & & & & & $\infty$ \\
\hline BG & $\mathrm{McPh}$ & Micro & Sarco & sm & Lauraceae & $\begin{array}{l}\text { Beilschmiedia acuta } \\
\text { Kosterm. }\end{array}$ & & & $a$ & & & & & & & & $\infty$ & & N & N & & & -1 & - & - & & & & & & & & & & & $a$ \\
\hline $\mathbf{C a}$ & $\mathrm{McPh}$ & Méso & Sarco & $\begin{array}{l}\mathrm{bm}+ \\
\mathrm{sm}\end{array}$ & Lauraceae & $\begin{array}{l}\text { Beilschmiedia } \\
\text { crassipes } \\
\text { \&Wilezek(Engl. \& K. } \\
\text { Krause) Robyns\& } \\
\text { Wilezek }\end{array}$ & $\infty$ & -7 & & & & & & & & -1 & $\infty$ & $\theta$ & a & N & & & & & & & N & & & & & & & & & $\cong$ \\
\hline CG & $\mathrm{McPh}$ & Méso & Sarco & sm & Comariopsidaceae & $\begin{array}{l}\text { Bolbitis gaboonensis } \\
\text { (Hook.)Alston }\end{array}$ & & & & & -7 & & & & & & -1 & & & & & & & & & & & & & & & & & & & - \\
\hline G & $\mathrm{McPh}$ & Méso & Sarco & sm & Simaroubaceae & $\begin{array}{l}\text { Brucea guineensis } \mathrm{G} . \\
\text { Don }\end{array}$ & & & 7 & & N & & & & & & N & -7 & & & & & & & & & & & & & & & & & & $m$ \\
\hline
\end{tabular}




\begin{tabular}{|c|c|c|c|c|c|c|c|c|c|c|c|c|c|c|c|c|c|c|c|c|c|c|c|c|c|c|c|c|c|c|c|c|c|c|c|c|c|}
\hline \multirow[b]{2}{*}{$\hat{H}$} & \multirow[b]{2}{*}{$\stackrel{\theta}{*}$} & \multirow[b]{2}{*}{ 至 } & \multirow[b]{2}{*}{ ? } & \multirow[b]{2}{*}{ 焉 } & \multirow[b]{2}{*}{ : } & \multirow[b]{2}{*}{ 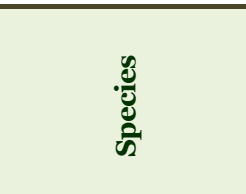 } & \multicolumn{11}{|c|}{ Plots } & \multicolumn{20}{|c|}{ Average class of diameter } \\
\hline & & & & & & & $\approx$ & ๙ี & $\ddot{\approx}$ & 2 & 2 & $\stackrel{2}{\simeq}$ & $\stackrel{1}{=}$ & 论 & $\stackrel{\infty}{\approx}$ & 2 & $\stackrel{\circ}{2}$ & $\stackrel{10}{10}$ & น̂̀ & $\overbrace{}^{16}$ & "ి & $\stackrel{10}{9}$ & مी & $\stackrel{10}{0}$ & $\stackrel{10}{1}$ & $\stackrel{10}{\infty}$ & ล̊ & $\stackrel{10}{0}$ & $\stackrel{10}{=}$ & ลี่ & คొ & $\frac{10}{1}$ & 10 & $\frac{10}{10}$ & $\frac{10}{12}$ & ${ }^{10}$ & 苞 \\
\hline BG & $\mathrm{MsPh}$ & Méso & Sarco & $\begin{array}{l}\mathrm{bm}+ \\
\mathrm{sm}\end{array}$ & Flacourtiaceae & $\begin{array}{l}\text { Caloncoba glauca (P. } \\
\text { Beauv.) Gilg }\end{array}$ & & -1 & & & & & & & & & & & - & & & & & & & & & & & & & & & & & & -1 \\
\hline BG & $\mathrm{McPh}$ & Macro & Sarco & $\mathrm{bm}$ & Ochnaceae & $\begin{array}{l}\text { Campylospermum } \\
\text { elongatum (Oliv.) } \\
\text { Tiegh. }\end{array}$ & & & & - & & & & & & & & - & & & & & & & & & & & & & & & & & & & -1 \\
\hline CG & $\mathrm{NnPh}$ & Méso & Sarco & sm & Rubiaceae & $\begin{array}{l}\text { Canthium vulgare (K. } \\
\text { Schum.)Bullock }\end{array}$ & & & & & & ○ & & & & & & $a$ & & & & & & & & & & & & & & & & & & & $a$ \\
\hline Aam & $\mathrm{MsPh}$ & Méso & Sarco & $\begin{array}{l}\mathrm{bm}+ \\
\mathrm{sm}\end{array}$ & Meliaceae & Carapa procera.D C & & & & - & & 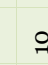 & & & N & -7 & m & 0 & - & 4 & - & N & & -7 & a & -1 & -1 & - & -1 & & -1 & - & & & & -1 & กิ \\
\hline GC & $\mathrm{McPh}$ & Micro & Sarco & $\mathrm{sm}$ & Polygalaceae & $\begin{array}{l}\text { Carpolobia alba G. } \\
\text { Don }\end{array}$ & & & - & & & & & & & & & & & & & - & & & & & & & & & & & & & & & - \\
\hline GC & $\mathrm{MsPh}$ & Macro & Sarco & $\mathrm{bm}$ & Sapotaceae & $\begin{array}{l}\text { Chrysophyllum } \\
\text { africanum A. DC. }\end{array}$ & & & & - & & & & & & & & & & & & & & & & & -1 & & & & & & & & & & -1 \\
\hline CG & $\mathrm{MsPh}$ & Méso & Sarco & $\begin{array}{l}\mathrm{bm}+ \\
\mathrm{sm}\end{array}$ & Sapotaceae & $\begin{array}{l}\text { Chrysophyllum } \\
\text { lacourtianum De } \\
\text { Wild. }\end{array}$ & & -1 & -1 & & & & & & & -1 & $r$ & & $N$ & & & - & & & & & -1 & & & & & & & & & & r \\
\hline GC & Phgr & Méso & Sarco & sm & Sapotaceae & $\begin{array}{l}\text { Chrysophyllum } \\
\text { welwitschii Engl. }\end{array}$ & & & & & & - & & & & & & & & & & -1 & & -1 & & & & & & & & & & & & & N \\
\hline BG & $\mathrm{NnPh}$ & Micro & Sarco & mi & Vitaceae & $\begin{array}{l}\text { Cissus amoena Gilg \& } \\
\text { Brandt }\end{array}$ & & & & & & & & & & & N & $\rightarrow$ & - & & & & & & & & & & & & & & & & & & N \\
\hline At & $\mathrm{NnPh}$ & Micro & Sarco & $\begin{array}{l}\mathrm{bm}+ \\
\mathrm{sm}\end{array}$ & Vitaceae & $\begin{array}{l}\text { Cissus aralioides } \\
\text { (Welw.ex Baker) } \\
\text { Planch }\end{array}$ & & & & -1 & & & & & & & & & & & - & & & & & & & & & & & & & & & & -1 \\
\hline CG & $\mathrm{NnPh}$ & Micro & Sarco & sm & Vitaceae & $\begin{array}{l}\text { Cissus barbeyana De } \\
\text { Wild. \& T. Durand }\end{array}$ & & & & & & & & & - & & & & & - & $\pi$ & & & & & & & & & & & & & & & & - \\
\hline At & $\mathrm{McPh}$ & Méso & Sarco & $\begin{array}{l}\mathrm{sm}+ \\
\mathrm{mi}\end{array}$ & Rutaceae & $\begin{array}{l}\text { Clausena anisata } \\
\text { (Willd.) Hook. f. ex } \\
\text { Benth }\end{array}$ & & & & & & - & & & & & & & - & & & & & & & & & & & & & & & & & & - \\
\hline GC & $\mathrm{MsPh}$ & Méso & Sarco & $\mathrm{bm}$ & Annonaceae & $\begin{array}{l}\text { Cleistopholis patens. } \\
\text { (Benth.)Engl \& Diels }\end{array}$ & & & -1 & & & & & & & & & & & & & & & & -7 & & & & & & & & & & & & - \\
\hline CG & $\mathrm{MsPh}$ & Méso & Sarco & $\mathrm{bm}$ & Myristicaceae & $\begin{array}{l}\text { Coelocaryon preussii } \\
\text { Warb. }\end{array}$ & & & & - & & & & & & & & & & & & & & -1 & & & & & & & & & & & & & - \\
\hline $\mathbf{C a}$ & $\mathrm{NnPh}$ & Micro & Sarco & sm & Rubiaceae & $\begin{array}{l}\text { Coffea bakossii Cheek } \\
\text { \& Bridson }\end{array}$ & & & & & & & & & a & & & $\rightarrow$ & & $a$ & ৯ & & & & & & & & & & & & & & & & $\infty$ \\
\hline $\mathbf{C a}$ & $\mathrm{NnPh}$ & Micro & Sarco & sm & Rubiaceae & $\begin{array}{l}\text { Coffea } \\
\text { montekupensis } \\
\text { Stoffelen }\end{array}$ & & & & & & & & & & & & & & & - & & & & & & & & & & & & & & & & -1 \\
\hline G & $\mathrm{MsPh}$ & Méso & Sarco & $\begin{array}{l}\mathrm{sm}+ \\
\mathrm{mi}\end{array}$ & Malvaceae & $\begin{array}{l}\text { Cola acuminata } \\
\text { (P.Beau.) Schott et } \\
\text { Endl }\end{array}$ & - & $m$ & & - & 4 & $4-$ & & & $\wedge$ & 10 & $\infty$ & J & $\infty$ & 0 & 6 & เ & a & a & $\infty$ & & -1 & N & & 7 & & & & & & & f \\
\hline BG & $\mathrm{McPh}$ & Méso & Sarco & $\begin{array}{l}\mathrm{bm}+ \\
\mathrm{sm}\end{array}$ & Malvaceae & Cola cauliflora Mast. & $r$ & $m$ & & - & & & & & & & & $\infty$ & - & & & 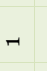 & & & & & & & & & & & & & & & is \\
\hline CG & $\mathrm{MsPh}$ & Méso & Sarco & $\mathrm{bm}+$ & Malvaceae & Cola grandifolia & a & -1 & -1 & & -1 & & & & & & & $\infty$ & ㄱ & r & $m$ & a & $\rightarrow$ & N & -7 & & & $\rightarrow$ & & & & & & & & & ळ్సి \\
\hline Aam & $\mathrm{MsPh}$ & Méso & Sarco & $\mathrm{sm}$ & Malvaceae & $\begin{array}{l}\text { Cola verticillata } \\
\text { (Thonn.) Stapf ex A. } \\
\text { Chev. }\end{array}$ & & & & -1 & & & & & & & & & & & & & & & & & -7 & & & & & & & & & & - \\
\hline & Phgr & & & sm & Combretaceae & Combretaceae liane & 0 & $a$ & & & & & & & & & & $n$ & 0 & $a$ & ง & & & & & & & & & & & & & & & & 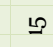 \\
\hline GC & Phgr & Nano & Scléro & $\begin{array}{l}\mathrm{bm}+ \\
\mathrm{sm}\end{array}$ & Combretaceae & $\begin{array}{l}\text { Combretum } \\
\text { bracteatum (M. A. } \\
\text { Lawson) Engl. \& } \\
\text { Diels }\end{array}$ & & & & $m$ & & - & & & 10 & & & $\Rightarrow$ & $r$ & -7 & $\pi$ & & & & & & & & & & & & & & & & 9 \\
\hline At & Phgr & Nano & Scléro & $\begin{array}{l}\mathrm{sm}+ \\
\mathrm{mi}\end{array}$ & Combretaceae & $\begin{array}{l}\text { Combretum } \\
\text { paniculatum Vent. }\end{array}$ & & & & & & & & & $\wedge$ & $\infty$ & N & $a$ & - & a & N & & & & & & & & & & & & & & & & $\cong$ \\
\hline
\end{tabular}

T. J. M. Tchoua and E. Noumi (2016) / Structure and Floristic Diversity of the Woody Vegetation of the Mount Kupe Submontane Forest (Moungo - Cameroon) 


\begin{tabular}{|c|c|c|c|c|c|c|c|c|c|c|c|c|c|c|c|c|c|c|c|c|c|c|c|c|c|c|c|c|c|c|c|c|c|c|c|c|c|}
\hline \multirow[b]{2}{*}{ E } & \multirow[b]{2}{*}{ 晀 } & \multirow[b]{2}{*}{ 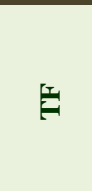 } & \multirow[b]{2}{*}{ li } & \multirow[b]{2}{*}{$\underline{ت}$} & \multirow[b]{2}{*}{ 氖 } & \multirow[b]{2}{*}{ 造 } & \multicolumn{10}{|c|}{ Plots } & \multicolumn{21}{|c|}{ Average class of diameter } \\
\hline & & & & & & & 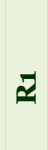 & $\approx$ & $\dddot{\varkappa}$ & 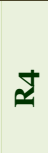 & $\approx$ & $\approx$ & $\hat{\approx}$ & $\stackrel{\infty}{\varkappa}$ & $\hat{\approx}$ & 党 & $\stackrel{10}{10}$ & คี & î & to & $\stackrel{10}{4}$ & คी & ஜ̊ & $\stackrel{19}{6}$ & ${ }^{10}$ & ถ์ & है & 10 & $\stackrel{10}{0}$ & מิ & ڤึ & 章 & ลี & $\stackrel{10}{0}$ & $\stackrel{\frac{10}{a}}{\frac{1}{a}}$ & $\frac{\infty}{10}$ & 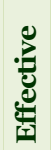 \\
\hline BG & $\mathrm{McPh}$ & Méso & Sarco & sm & Boraginaceae & $\begin{array}{l}\text { Cordia aurantiaca } \\
\text { Bak. }\end{array}$ & & & -1 & & & & & & & & & & & & $\rightarrow$ & & & & & & & & & & & & & & & & $\rightarrow$ \\
\hline BG & $\mathrm{McPh}$ & Macro & Sarco & sm & Lecythidaceae & $\begin{array}{l}\text { Crateranthus } \\
\text { talbotiïBak. F. }\end{array}$ & & & & & N & & & & & & & -1 & -1 & & & & & & & & & & & & & & & & & & N \\
\hline BG & $\mathrm{McPh}$ & Micro & Pogo & $\mathrm{mi}$ & Euphorbiaceae & $\begin{array}{c}\text { Crotonogyne } \\
\text { preussiiPax }\end{array}$ & & & & & & & & & -7 & & & & & & & & & & & & & & - & & & & & & & & -1 \\
\hline At & Phgr & Micro & Pogo & $\mathrm{mi}$ & Periplocaceae & $\begin{array}{l}\text { Cryptolepis } \\
\text { sanguinolenta } \\
\text { (Lindl.) Schltr. }\end{array}$ & & & & & & & & & & - & & & - & - & & & & & & & & & & & & & & & & & -1 \\
\hline BG & $\mathrm{McPh}$ & Méso & Sarco & sm & Rubiaceae & $\begin{array}{l}\text { Cuviera longiflora } \\
\text { Hierns }\end{array}$ & & & -1 & & & & & & & & & -1 & & & & & & & & & & & & & & & & & & & -7 \\
\hline $\mathbf{C a}$ & $\mathrm{NnPh}$ & Lepto & Scléro & $\mathrm{mi}$ & Cyatheaceae & $\begin{array}{l}\text { Cyathea } \\
\text { camerooniana } \\
\text { Hook.var.zenkeri } \\
\text { (Diels) Tardieu }\end{array}$ & & & & & & & & & N & & & -1 & -1 & r & & & & & & & & & & & & & & & & & $\mathrm{N}$ \\
\hline $\mathbf{C a}$ & $\mathrm{MsPh}$ & Méga & Sarco & sm & Caricaceae & $\begin{array}{l}\text { Cylicomorpha somlii } \\
\text { (Urb.) Urb. }\end{array}$ & - & & & -7 & & N & & -7 & & & & - & & & - & & & a & & - & & & & & & & & & & & เo \\
\hline At & $\mathrm{MsPh}$ & Méso & Sarco & $\begin{array}{l}\mathrm{bm}+ \\
\mathrm{sm}\end{array}$ & Leguminosae & $\begin{array}{l}\text { Daniellia oliveri } \\
\text { (Rolfe) Hutch. \& } \\
\text { Dalziel }\end{array}$ & & -7 & & & & & & & & & & & & & & & & & & -1 & & & & & & & & & & & -1 \\
\hline GC & $\mathrm{McPh}$ & Méso & Scléro & $\mathrm{sm}$ & Sapindaceae & $\begin{array}{l}\text { Deinbollia sp. aff. } \\
\text { maxima Gilg }\end{array}$ & & -1 & & & & & & & & & -1 & & & & & & & & & & & & & & & & & & & & -7 \\
\hline CG & $\mathrm{McPh}$ & Méso & Scléro & sm & Sapindaceae & $\begin{array}{l}\text { Deinbollia } \\
\text { rambaensis Pellegr. }\end{array}$ & & -1 & & & & & & & & & & -1 & & & & & & & & & & & & & & & & & & & - \\
\hline GC & $\mathrm{McPh}$ & Méso & Baro & $\begin{array}{l}\mathrm{bm}+ \\
\mathrm{sm}\end{array}$ & Tiliaceae & $\begin{array}{l}\text { Desplatsia dewevrei } \\
\text { (De Wild. \& T. } \\
\text { Durand) }\end{array}$ & -1 & $m$ & & -1 & & & & & & & $\infty$ & -1 & 4 & - & & & & & & & & & & & & & & & & & is \\
\hline $\mathbf{C a}$ & $\mathrm{NnPh}$ & Micro & Sarco & $\underset{\mathrm{mi}}{\mathrm{sm}}+$ & Thymeliaceae & $\begin{array}{l}\text { Dicranolepis vestita } \\
\text { Engl. }\end{array}$ & & & & & & N & & $\stackrel{\circ}{\circ}$ & $m$ & $\wedge$ & $\infty$ & $\sigma$ & $a$ & $m$ & $r$ & & - & & & & & & & & & & & & & & สิ \\
\hline At & $\mathrm{NnPh}$ & Micro & Sarco & $\mathrm{sm}$ & Agavaceae & $\begin{array}{l}\text { Dracaena fragrans } \\
\text { (L.) Ker-Gawl. }\end{array}$ & & & & & & & & -1 & & & $\infty$ & & & & & & & & & & & & & & & & & & & & $m$ \\
\hline G & $\mathrm{NnPh}$ & Micro & Sarco & $\mathrm{mi}$ & Agavaceae & $\begin{array}{l}\text { Dracaena sp. aff. } \\
\text { Phrynioides Hook. }\end{array}$ & & & & & & & & & -1 & -1 & -1 & & - & - & & & & & & & & & & & & & & & & & N \\
\hline G & $\mathrm{MsPh}$ & Méso & Sarco & Large & Euphorbiaceae & $\begin{array}{l}\text { Drypetes leonensis } \\
\text { Pax }\end{array}$ & N & 0 & $\cong$ & $m$ & @ & N & & -1 & - & $\wedge$ & 9 & 웅 & a & $m$ & 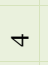 & $\infty$ & N & N & & - & & & - & & & & $r$ & & & & $q$ \\
\hline BG & $\mathrm{MsPh}$ & Méso & Sarco & $\begin{array}{l}\mathrm{sm}+ \\
\mathrm{mi}\end{array}$ & Euphorbiaceae & $\begin{array}{l}\text { Drypetes preussii ( } \\
\text { Pax) Hutch. }\end{array}$ & & 10 & -1 & & $\infty$ & $m$ & & N & - & & $\infty$ & & 。 & v & $r$ & & - & - & - & & & & & & & & & - & & & $\longmapsto$ \\
\hline BG & $\mathrm{McPh}$ & Méso & Sarco & $\begin{array}{l}\mathrm{bm}+ \\
\mathrm{sm}\end{array}$ & Sapotaceae & $\begin{array}{l}\text { Englerophytum } \\
\text { stelechanthum KK. } \\
\text { Krause }\end{array}$ & - & $\infty$ & สี & & $\Lambda$ & & & & & & I & $\theta$ & + & v & 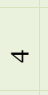 & a & & N & N & N & v & r & & & & & & & & & m \\
\hline GC & $\mathrm{MsPh}$ & Méso & Sarco & $\begin{array}{l}\mathrm{sm}+ \\
\mathrm{mi}\end{array}$ & Meliaceae & $\begin{array}{l}\text { Entandrophragma } \\
\text { angolense (Welw.) } \\
\text { C.CD. }\end{array}$ & & & & & -1 & -7 & & & & - & $m$ & -1 & & & & & & & & & & & & & & & & & & & + \\
\hline GC & $\mathrm{MsPh}$ & Méso & Sarco & $\mathrm{sm}$ & Fabaceae & $\begin{array}{l}\text { Erythrina } \\
\text { mildbraedii Harms }\end{array}$ & & - & & & & & & & & & & & & & & & & & -1 & & & & & & & & & & & & - \\
\hline G & $\mathrm{McPh}$ & Micro & Sarco & $\mathrm{mi}$ & Euphorbiaceae & $\begin{array}{l}\text { Erythrococca } \\
\text { anomala (Juss. Ex } \\
\text { Poir.) Prain }\end{array}$ & & & & & & & & & & -1 & $\rightarrow$ & & & & & & & & & & & & & & & & & & & & -1 \\
\hline GC & $\mathrm{McPh}$ & Méso & Sarco & $\begin{array}{l}\mathrm{bm}+ \\
\mathrm{sm}\end{array}$ & Myrtaceae & $\begin{array}{l}\text { Eugenia obanensis } \\
\text { Bak.f. }\end{array}$ & N & -1 & $a$ & t & $a$ & & & $r$ & & -7 & $\wedge$ & $\infty$ & r & $\wedge$ & N & N & & -7 & & & & & & & & & & & & & $\widehat{\widehat{N}}$ \\
\hline Pal & $\mathrm{MsPh}$ & Méso & Sarco & $\mathrm{bm}$ & Moraceae & $\begin{array}{l}\text { Ficus exasperata } \\
\text { Vahl. }\end{array}$ & & & & & & - & & & & & & & 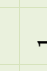 & 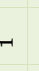 & & & & & & & & & & & & & & & & & $\rightarrow$ \\
\hline GC & $\mathrm{MgPh}$ & Méso & Sarco & $\mathrm{bm}$ & Moraceae & $\begin{array}{l}\text { Ficus mucuso } \\
\text { Welw.ex Ficalho }\end{array}$ & & & & & & t & & & & & a & - & & & & & & & & & 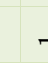 & - & & & & & & & & & + \\
\hline
\end{tabular}

T. J. M. Tchoua and E. Noumi (2016) / Structure and Floristic Diversity of the Woody Vegetation of the Mount Kupe Submontane Forest (Moungo - Cameroon) 


\begin{tabular}{|c|c|c|c|c|c|c|c|c|c|c|c|c|c|c|c|c|c|c|c|c|c|c|c|c|c|c|c|c|c|c|c|c|c|c|c|c|c|}
\hline \multirow[b]{2}{*}{ F } & \multirow[b]{2}{*}{ 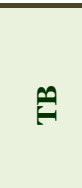 } & \multirow[b]{2}{*}{ 至 } & \multirow[b]{2}{*}{ 至 } & \multirow[b]{2}{*}{ 晃 } & \multirow[b]{2}{*}{ 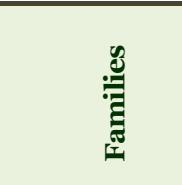 } & \multirow[b]{2}{*}{$\begin{array}{l}e_{0}^{2} \\
\frac{\mathscr{E}}{2}\end{array}$} & \multicolumn{10}{|c|}{ Plots } & \multicolumn{21}{|c|}{ Average class of diameter } \\
\hline & & & & & & & $\bar{z}$ & $\approx$ & $\dddot{\varkappa}$ & 茫 & $\approx$ & $\stackrel{0}{\sim}$ & $\approx$ & $\stackrel{\infty}{\approx}$ & $\approx$ & $\stackrel{0}{2}$ & 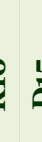 & 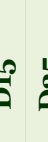 & ลี & ڤొ & $\frac{10}{4}$ & 10 & เి & If & o & 10 & ட̊̊ & $\stackrel{10}{\circ}$ & $\stackrel{10}{=1}$ & ลี & ڤึ & $\stackrel{10}{1}$ & ลี & है & $\frac{10}{1}$ & $\stackrel{\infty}{\infty}$ & 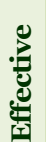 \\
\hline CG & $\mathrm{MsPh}$ & Micro & Sarco & $\begin{array}{l}\mathrm{bm}+ \\
\mathrm{sm}\end{array}$ & Moraceae & $\begin{array}{l}\text { Ficus ottoniifolia } \\
\text { (Miq.) Miq.subsp. } \\
\text { Ottoniifolia }\end{array}$ & & & & & & & & & 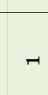 & & & & & & & & & & & & & -1 & & & & & & & & & -1 \\
\hline At & $\mathrm{MsPh}$ & Méso & Sarco & $\begin{array}{l}\mathrm{sm}+ \\
\mathrm{mi}\end{array}$ & Moraceae & Ficus sur Forssk. & & & -1 & $-r$ & & $\theta$ & & & a & -1 & -1 & $m$. & 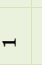 & & & & - & - & & & & -7 & & a & & & & & & & $a$ \\
\hline At & $\mathrm{MsPh}$ & Micro & Sarco & $\mathrm{bm}+$ & Moraceae & $\begin{array}{l}\text { Ficus trichopoda } \\
\text { Baker }\end{array}$ & & & & & & - & & & & & & & 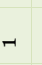 & & & & & & & & & & & & & & & & & & - \\
\hline BG & $\mathrm{McPh}$ & Méso & Sarco & $\mathrm{sm}$ & Clusiaceae & $\begin{array}{l}\text { Garcinia lucida } \\
\text { Vesque }\end{array}$ & & & & ส & & & & & & & 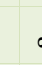 & a & $\wedge$ & $\infty$ & $\nabla$ & $\infty$ & -1 & - & & & & & & & & & & & & & ส \\
\hline BG & $\mathrm{McPh}$ & Méso & Sarco & $\begin{array}{l}\mathrm{sm}+ \\
\mathrm{mi}\end{array}$ & Clusiaceae & Garcinia mannii Oliv. & & - & -1 & & & - & & & $\rightarrow$ & - & -1 & مו & & & & -7 & & & & & & & & & & & & & & & 0 \\
\hline GC & $\mathrm{McPh}$ & Méso & Sarco & $\begin{array}{l}\mathrm{sm}+ \\
\mathrm{mi}\end{array}$ & Clusiaceae & $\begin{array}{l}\text { Garcinia } \\
\text { smeathmannii } \\
\text { (Planch.\& Triana) } \\
\text { Oliv. }\end{array}$ & & & -1 & & a & & & & -1 & $r$ & - & - & - & -7 & - & $\theta$ & a & & & & -7 & & & & & & & & & & $\exists$ \\
\hline GC & $\mathrm{McPh}$ & Méso & Sarco & $\mathrm{bm}$ & Rubiaceae & $\begin{array}{l}\text { Gardenia vogelii } \\
\text { Hook. f.ex Planch. }\end{array}$ & - & & & & & & & & & & . & - & & & & & & & & & & & & & & & & & & & -7 \\
\hline GC & $\mathrm{MsPh}$ & Méso & Sarco & $\mathrm{sm}$ & Flacourtiaceae & $\begin{array}{l}\text { Homalium } \\
\text { africanum (Hook. f) } \\
\text { Benth. }\end{array}$ & & & & & - & & & & & & & & & & - & & & & & & & & & & & & & & & & -1 \\
\hline BG & $\mathrm{McPh}$ & Méso & Sarco & $\mathrm{bm}$ & Lauraceae & $\begin{array}{l}\text { Hypodaphnis zenkeri } \\
\text { (Engl.) Stapf }\end{array}$ & & & & & & - & & & & & & & & & & & & & ( & - & & & & & & & & & & & -7 \\
\hline GC & $\mathrm{NnPh}$ & Micro & Sarco & $\mathrm{sm}$ & Icacinaceae & Icacina mannii Oliv. & & & & -4 & & & & & & & & & 4 & & & & & & & & & & & & & & & & & & -1 \\
\hline BG & $\mathrm{McPh}$ & Méso & Scléro & $\mathrm{sm}$ & Sapindaceae & $\begin{array}{l}\text { Eriocoelum petiolare } \\
\text { Radlk. }\end{array}$ & & & & & & & & - & & & & & & & & & & & . & - & & & & & & & & & & & - \\
\hline G & $\mathrm{McPh}$ & Méso & Scléro & $\mathrm{bm}$ & Sapindaceae & $\begin{array}{l}\text { Eriocoelum } \\
\text { racemosum Baker }\end{array}$ & - & & & & & & & & & & , & - & & & & & & & & & & & & & & & & & & & -1 \\
\hline BG & $\mathrm{McPh}$ & Méso & Sarco & sm & Annonaceae & Isolona zenkeri Engl. & & & & & & N & & & & & 。 & ง & & & & & & & & & & & & & & & & & & & n \\
\hline CG & $\mathrm{NnPh}$ & Méso & Sarco & $\mathrm{sm}$ & Rubiaceae & $\begin{array}{l}\text { Ixora guineensis } \\
\text { Benth. }\end{array}$ & & t & & $\mathrm{N}$ & -1 & & & & & & & ما & a & $\pi$ & & & & & & & & & & & & & & & & & $\infty$ \\
\hline At & $\mathrm{McPh}$ & Méso & Pogo & $\mathrm{mi}$ & Bignoniaceae & $\begin{array}{l}\text { kigelia africana } \\
\text { (Lam.) Benth. }\end{array}$ & & & & & & & & & & $\curvearrowright$ & - & -1 & N & $\theta$ & & & & & & & & & & & & & & & & & 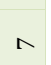 \\
\hline CG & $\mathrm{MsPh}$ & Méso & Sarco & $\mathrm{bm}$ & Euphorbiaceae & $\begin{array}{l}\text { Klaineanthus } \\
\text { gaboniae Pierre ex } \\
\text { Prain }\end{array}$ & & & & & -1 & & & & & & & & & & & & & & & & $\pi$ & & & & & & & & & & -1 \\
\hline BG & $\mathrm{McPh}$ & Méso & Sarco & $\begin{array}{l}\mathrm{sm}+ \\
\mathrm{mi}\end{array}$ & Sapindaceae & $\begin{array}{l}\text { Laccodiscus } \\
\text { ferrugineus (Baker) } \\
\text { Radlk. }\end{array}$ & & & a & & -1 & & & & & $m$ & 0 & a & $m$ & t & & & -1 & & & & & & & & & & & & & & \\
\hline GC & $\mathrm{MsPh}$ & Méso & Sarco & $\mathrm{bm}$ & Anacardiaceae & $\begin{array}{l}\text { Lannea welwitschii } \\
\text { (Hiern) Engl. }\end{array}$ & & & & & & - & & & & & 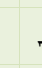 & - & & & & & & & & & & & & & & & & & & & -1 \\
\hline CG & Nnph & Micro & Sarco & sm & Icacinaceae & $\begin{array}{l}\text { Lasianthera africana } \\
\text { P. Beauv. }\end{array}$ & & & & N & & & & & & & r & ง & & & & & & & & & & & & & & & & & & & a \\
\hline At & $\mathrm{McPh}$ & Micro & Sarco & $\underset{\mathrm{mi}}{\mathrm{sm}+}$ & Leeaceae & $\begin{array}{l}\text { Leea guineensis G. } \\
\text { Don }\end{array}$ & & & & & & $m$ & & & & a & $v$ & 6 & - & & & & & & & & & & & & & & & & & & $\wedge$ \\
\hline $\mathbf{C a}$ & $\mathrm{McPh}$ & Méso & Sarco & $\mathrm{bm}+$ & Malvaceae & $\begin{array}{l}\text { Leptonychia pallida } \\
\text { K. Schum. }\end{array}$ & - & $\infty$ & & -1 & & & & & & & & ما & & & & & & & & & & & & & & & & & & & 10 \\
\hline $\mathbf{C a}$ & $\mathrm{MsPh}$ & Méso & Sarco & $\begin{array}{l}\mathrm{bm}+ \\
\mathrm{sm}\end{array}$ & Euphorbiaceae & $\begin{array}{l}\text { Macaranga } \\
\text { occidentalis (Müll. } \\
\text { Arg.) Müll.Arg. }\end{array}$ & -1 & & & & & $\infty$ & & & & & s & a & $m$ & a & -1 & -1 & a & & & & & & & & & & & & & & $\Rightarrow$ \\
\hline GC & $\mathrm{MsPh}$ & Méso & Sarco & $\mathrm{bm}$ & Rhamnaceae & $\begin{array}{l}\text { Maesopsis eminii } \\
\text { Engl. }\end{array}$ & - & & & & & & & & & & & & & & & & & & . & 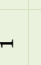 & & & & & & & & & & & -1 \\
\hline AM & $\mathrm{McPh}$ & Micro & Sarco & $\mathrm{bm}$ & Euphorbiaceae & $\begin{array}{l}\text { Mallotus } \\
\text { oppositifolius } \\
\text { (Geisel.) Müll. Arg. }\end{array}$ & & t & & & & & & & & & & & - & & & & & & & & & & & & & & & & & & -1 \\
\hline
\end{tabular}




\begin{tabular}{|c|c|c|c|c|c|c|c|c|c|c|c|c|c|c|c|c|c|c|c|c|c|c|c|c|c|c|c|c|c|c|c|c|c|c|c|c|c|c|}
\hline \multirow[b]{2}{*}{ E } & \multirow[b]{2}{*}{ 晀 } & \multirow[b]{2}{*}{ 瓷 } & \multirow[b]{2}{*}{ 尝 } & \multirow[b]{2}{*}{ 䄑 } & \multirow[b]{2}{*}{ 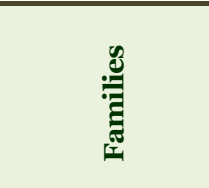 } & \multirow[b]{2}{*}{ 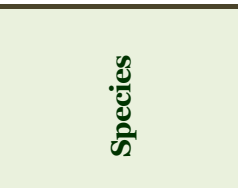 } & \multicolumn{11}{|c|}{ Plots } & \multicolumn{21}{|c|}{ Average class of diameter } \\
\hline & & & & & & & $\approx$ & $\approx$ & $\dddot{\varkappa}$ & $\approx$ & $\approx$ & $\approx$ & $\stackrel{1}{2}$ & $\stackrel{\infty}{=}$ & 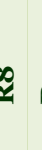 & 2 & $\stackrel{0}{2}$ & $\stackrel{10}{10}$ & ลิ & ตึ & $\frac{1}{18}$ & & مी & ถి & $\stackrel{10}{6}$ & 囱 & ล̊ & $\stackrel{10}{\theta}$ & $\frac{1}{2}$ & है & ลี & חొ & $\stackrel{18}{ \pm}$ & ลี & $\stackrel{10}{\circ}$ & $\stackrel{\frac{10}{a}}{\frac{1}{a}}$ & $\frac{10}{10}$ & 窇 \\
\hline GC & $\mathrm{MsPh}$ & Méso & Sarco & $\mathrm{bm}$ & Clusiaceae & $\begin{array}{l}\text { Mammea africana } \\
\text { Sabine }\end{array}$ & N & & & & & & & & & & & $r$ & -1 & & & & & & & & & & & & & & & & & & & N \\
\hline $\mathbf{C a}$ & $\mathrm{McPh}$ & Méso & Sarco & sm & Melastomataceae & $\begin{array}{l}\text { Memecylon } \\
\text { dasyanthum Gilg \& } \\
\text { Ledermann ex Engl. }\end{array}$ & & & a & - & a & & & & & & & $\infty$ & -1 & & & & - & & & & & & & & & & & & & & & م \\
\hline $\mathbf{C a}$ & $\mathrm{McPh}$ & Micro & Sarco & sm & Melastomataceae & $\begin{array}{l}\text { Memecylon griseo- } \\
\text { violaceum ex Gilg \& } \\
\text { Ledermann ex Engl. }\end{array}$ & & & a & & & & & & & & & - & -1 & & & & & & & & & & & & & & & & & & & $N$ \\
\hline G & $\mathrm{McPh}$ & Méso & Sarco & sm & Annonaceae & $\begin{array}{l}\text { Monodora brevipes } \\
\text { Benth. }\end{array}$ & & a & $\infty$ & & & & & & & & & + & -7 & & & & & & & & & & & & & & & & & & & in \\
\hline At & $\mathrm{MsPh}$ & Méso & Sarco & $\mathrm{mi}$ & Annonaceae & $\begin{array}{l}\text { Monodora myristica } \\
\text { (Gaertn.) Duanal }\end{array}$ & -7 & & & & & & & & & & & & & -1 & & & & & & & & & & & & & & & & & & $\rightarrow$ \\
\hline G & $\mathrm{McPh}$ & Méso & Sarco & sm & Annonaceae & $\begin{array}{l}\text { Monodora tenuifolia } \\
\text { Benth. }\end{array}$ & & & & & -1 & & & & & & & & & & -1 & & & & & & & & & & & & & & & & & $\rightarrow$ \\
\hline GC & $\mathrm{MsPh}$ & Macro & Sarco & $\begin{array}{l}\mathrm{bm}+ \\
\mathrm{sm}\end{array}$ & Cecropiaceae & $\begin{array}{l}\text { Musanga } \\
\text { cecropioides R.Br.ex } \\
\text { Tedlie }\end{array}$ & & & & & -1 & & & & & & & & & & & & - & & & & & & & & & & & & & & & -1 \\
\hline GC & $\mathrm{MsPh}$ & Méso & Sarco & $\begin{array}{l}\mathrm{bm}+ \\
\mathrm{sm}\end{array}$ & Rubiaceae & $\begin{array}{l}\text { Nauclea diderrichï } \\
\text { (De Wild. \& Th. } \\
\text { Dur.) Merrill }\end{array}$ & - & & & & & & & & & & & & & & & & & & & & & & & & & & & $\pi$ & & & & 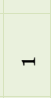 \\
\hline BG & $\mathrm{McPh}$ & Méso & Pogo & $\mathrm{bm}$ & Euphorbiaceae & $\begin{array}{l}\text { Neoboutonia mannii } \\
\text { Benth. var.mannii }\end{array}$ & & & & & & N & & & & & & - & & 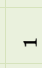 & & & & & & & & & & & & & & & & & & N \\
\hline Ca & $\mathrm{MsPh}$ & Méso & Sarco & $\underset{\mathrm{mi}}{\mathrm{sm}}+$ & Leguminosae & $\begin{array}{l}\text { Newtonia } \\
\text { duncanthomasii } \\
\text { Mackinder \& Cheek }\end{array}$ & & & & & & & & & ڤ & $\pi$ & & N & -1 & - & & & & & & & - & & & 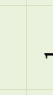 & 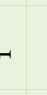 & & & & & & & 0 \\
\hline CG & $\mathrm{McPh}$ & Méso & Sarco & $\mathrm{mi}$ & Octoknemaceae & $\begin{array}{l}\text { Octoknema } \\
\text { genovefae Villiers }\end{array}$ & & & & & & & & & & - & & & -7 & & & & & & & & & & & & & & & & & & & -7 \\
\hline BG & $\mathrm{McPh}$ & Macro & Sarco & sm & Thymeliaceae & $\begin{array}{l}\text { Octolepis casearia } \\
\text { Oliv. }\end{array}$ & & & & & & & & & & & & - & t & - & $m$ & & - & $\rightarrow$ & & & & & & & & & & & & & & $\exists$ \\
\hline $\mathbf{C a}$ & $\mathrm{McPh}$ & Méso & Sarco & $\mathrm{sm}$ & Flacourtiaceae & Oncoba ovalis Oliv. & & & & & & -1 & & & & & & t & & & & & & & & & & & & & & & & & & & & -1 \\
\hline BG & $\mathrm{McPh}$ & Méso & Sarco & sm & Rutaceae & $\begin{array}{l}\text { Oricia lecomteana } \\
\text { Pierre }\end{array}$ & & & & -1 & & & & & & & & - & & & & & & & & & & & & & & & & & & & & -7 \\
\hline At & $\mathrm{McPh}$ & Méso & Sarco & $\begin{array}{l}\mathrm{bm}+ \\
\mathrm{sm}\end{array}$ & Ochnaceae & $\begin{array}{l}\text { Ouratea reticulata } \\
\text { (P. Beauv.) Engl. }\end{array}$ & - & & & & & & & & & & & & & & - & & & & & & & & & & & & & & & & & - \\
\hline GC & $\mathrm{McPh}$ & Méso & Sarco & sm & Rubiaceae & $\begin{array}{l}\text { Oxyanthus pallidus } \\
\text { Hiern }\end{array}$ & & & $\rightarrow$ & & & & & & & & & & - & & & & & & & & & & & & & & & & & & & 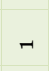 \\
\hline GC & $\mathrm{MsPh}$ & Lepto & Sarco & $\mathrm{bm}$ & Leguminosae & $\begin{array}{l}\text { Parkia bicolor A. } \\
\text { Chev. }\end{array}$ & & & & & $\neg$ & & & & & & & & & & & & & & & & & & & & & 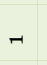 & & & & & & - \\
\hline CG & $\mathrm{NnPh}$ & Macro & Sarco & $\begin{array}{l}\mathrm{bm}+ \\
\mathrm{sm}\end{array}$ & Menispermaceae & $\begin{array}{l}\text { Penianthus } \\
\text { longifolius Miers }\end{array}$ & $=$ & 온 & ๙ิ & สี & N & & & & & & & ఉ & ส & - & -1 & & & & & & & & & & & & & & & & & $\hat{ᄋ}$ \\
\hline At & $\mathrm{NnPh}$ & Micro & Sarco & $\mathrm{mi}$ & Piperaceae & $\begin{array}{l}\text { Peperomia pallucida } \\
\text { (L.) Kunth }\end{array}$ & & & & & & & & & & & -1 & - & & & & & & & & & & & & & & & & & & & & - \\
\hline At & $\mathrm{McPh}$ & Méso & Sarco & $\underset{\mathrm{mi}}{\mathrm{sm}}+$ & Piperaceae & $\begin{array}{l}\text { Piper capense } \\
\text { Schumach. \& } \\
\text { Thonn. Cf. }\end{array}$ & & & & & & -1 & & & & $\infty$ & & + & & & & & & & & & & & & & & & & & & & & $\nabla$ \\
\hline G & $\mathrm{NnPh}$ & Méso & Sarco & $\mathrm{mi}$ & Piperaceae & $\begin{array}{l}\text { Piper umbellatum } \\
\text { Linn. }\end{array}$ & & & & & & & & & & 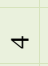 & & $\theta$ & & & & & & & & & & & & & & & & & & & & 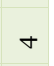 \\
\hline BG & $\mathrm{McPh}$ & Méso & Sarco & $\underset{\mathrm{mi}}{\mathrm{sm}}+$ & Sapindaceae & $\begin{array}{l}\text { Placodiscus opacus } \\
\text { Radlk. }\end{array}$ & & & & & & & & 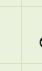 & ง & $\bumpeq$ & $\stackrel{ }{=}$ & ลิ & $\wedge$ & & - & & & & & & & & & & & & & & & & & 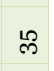 \\
\hline At & $\mathrm{MsPh}$ & Méso & Sarco & $\mathrm{sm}_{\mathrm{mi}}^{+}$ & Araliaceae & $\begin{array}{l}\text { Polyscias fulva } \\
\text { (Hiern) Harms }\end{array}$ & & & & & & & & & & & N & & & N & $r$ & & & & -1 & & & & & & & & & & & & & 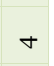 \\
\hline At & $\mathrm{MsPh}$ & Méso & Sarco & $\mathrm{sm}$ & Rosaceae & $\begin{array}{l}\text { Prumus africana } \\
\text { (Hook.f) Kalkm }\end{array}$ & & & & & & & & 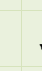 & -1 & & & & & & & & & $\rightarrow$ & & & & & & & & & & & & & & - \\
\hline GC & $\mathrm{McPh}$ & Méso & Sarco & $\mathrm{mi}$ & Rubiaceae & $\begin{array}{l}\text { Psychotria gabonica } \\
\text { Hiern }\end{array}$ & & & & & & & & & & & -1 & $r$ & & & & & & & & & & & & & & & & & & & & - \\
\hline
\end{tabular}

T. J. M. Tchoua and E. Noumi (2016) / Structure and Floristic Diversity of the Woody Vegetation of the Mount Kupe Submontane Forest (Moungo - Cameroon) 


\begin{tabular}{|c|c|c|c|c|c|c|c|c|c|c|c|c|c|c|c|c|c|c|c|c|c|c|c|c|c|c|c|c|c|c|c|c|c|c|c|c|c|}
\hline \multirow[b]{2}{*}{$\hat{z}$} & \multirow[b]{2}{*}{$\stackrel{\sim}{*}$} & \multirow[b]{2}{*}{ 留 } & \multirow[b]{2}{*}{ li } & \multirow[b]{2}{*}{ 㱐 } & \multirow[b]{2}{*}{ 总 } & \multirow[b]{2}{*}{ 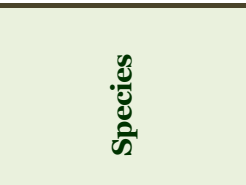 } & \multicolumn{10}{|c|}{ Plots } & \multicolumn{21}{|c|}{ Average class of diameter } \\
\hline & & & & & & & $\underline{q}$ & $\dddot{2}$ & $\ddot{\varkappa}$ & 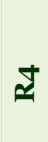 & 2 & $\approx$ & $\hat{\approx}$ & $\stackrel{\infty}{\varkappa}$ & $\approx$ & $\frac{0}{2}$ & $\stackrel{10}{10}$ & กิ & & డొ & $\stackrel{10}{+1}$ & 10 & $\stackrel{10}{6}$ & $\stackrel{10}{6}$ & $\stackrel{10}{\infty}$ & ล̊ & $\stackrel{10}{\circ}$ & $\frac{1}{2}$ & $\frac{1}{2}$ & ลี & ڤి & $\frac{18}{4}$ & $\overbrace{}^{10}$ & है & $\stackrel{10}{\frac{10}{2}}$ & $\stackrel{\infty}{\infty}$ & 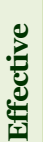 \\
\hline CG & $\mathrm{McPh}$ & Méso & Sarco & $\begin{array}{l}\mathrm{sm}+ \\
\mathrm{mi}\end{array}$ & Rubiaceae & $\begin{array}{l}\text { Psychotria globosa } \\
\text { Hiern var. globosa }\end{array}$ & & & & & & & & $\dddot{\sim}$ & in & $\exists$ & สิ & $r$ & & & & & & & & & & & & & & & & & & & ลิ \\
\hline At & $\mathrm{McPh}$ & Méso & Sarco & $\mathrm{sm}+$ & Rubiaceae & $\begin{array}{l}\text { Psychotria } \\
\text { pedoncularis } \\
\text { (Salisb.) } \\
\text { Steyerm.var. } \\
\text { pedoncularis }\end{array}$ & & & & & & & & N & 10 & 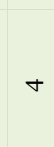 & 0 & L & & - & & & & & & & & & & & & & & & & & ㄱ \\
\hline $\mathbf{C a}$ & $\mathrm{NnPh}$ & Méso & Sarco & sm & Rubiaceae & $\begin{array}{l}\text { Psychotria sp. aff. } \\
\text { Subobliqua Hiern }\end{array}$ & & $\cong$ & 0 & 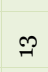 & -1 & & & & & & 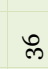 & ㄱำ & & & & & & & & & & & & & & & & & & & $\stackrel{\infty}{q}$ \\
\hline At & $\mathrm{McPh}$ & Méso & Sarco & $\mathrm{mi}$ & Rubiaceae & $\begin{array}{l}\text { Psychotria } \\
\text { succulenta (Hiern) } \\
\text { Petit }\end{array}$ & & & & & & & & & 0 & & م & -7 & & & & & & & & & & & & & & & & & & & 0 \\
\hline GC & $\mathrm{MgPh}$ & Macro & Sarco & $\mathrm{bm}$ & Myristicaceae & $\begin{array}{l}\text { Pycnanthus } \\
\text { angolensis (Welw.) } \\
\text { Warb. }\end{array}$ & a & -1 & & & N & $\wedge$ & & & & & $\wedge$ & $a$ & & & & & & & & & & & & & & -7 & & - & -7 & & $\cong$ \\
\hline $\mathbf{C a}$ & $\mathrm{MsPh}$ & Méso & Sarco & sm & Simaroubaceae & $\begin{array}{l}\text { Quassia sanguinea } \\
\text { Cheek \& Jondkind } \\
\text { ined. }\end{array}$ & & -1 & & & & & & & & & 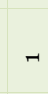 & & & & & & & & & & & & & & & & & & & & -1 \\
\hline GC & $\mathrm{McPh}$ & Méso & Sarco & sm & Simaroubaceae & $\begin{array}{l}\text { Quassia silvestris } \\
\text { Cheek \& Jondlind } \\
\text { ined. }\end{array}$ & & & a & & & & & & & & -1 & & & - & & & & & & & & & & & & & & & & & a \\
\hline CG & $\mathrm{NnPh}$ & Macro & Sarco & sm & Violaceae & $\begin{array}{l}\text { Rinorea gabunensis } \\
\text { Engl. }\end{array}$ & & & - & & & & & & & & & & & & & -1 & & & & & & & & & & & & & & & -1 \\
\hline GC & $\mathrm{Ms} \mathrm{Ph}$ & Méso & Sarco & sm & Rubiaceae & $\begin{array}{l}\text { Rothmannia hispida } \\
\text { (K. Schum.) } \\
\text { Fagerlind }\end{array}$ & & & 0 & & N & & & & & & $\infty$ & a & & - & & & & & & & & & & & & & & & & & $\infty$ \\
\hline BG & $\mathrm{NnPh}$ & Méso & Sarco & $\mathrm{mi}$ & Rubiaceae & Rutidea glabra Hiern & & & & & & & & & & -1 & & - & & & & & & & & & & & & & & & & & & & -7 \\
\hline CG & Phgr & Méso & Sarco & $\mathrm{mi}$ & Celastraceae & $\begin{array}{l}\text { Salacia loloensis } \\
\text { Loes.var.loloensis }\end{array}$ & & & & & & & & & a & t & L & 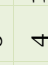 & + & ナ & & & & & & & & & & & & & & & & & 익 \\
\hline BG & Phgr & Méso & Sarco & sm & Celastraceae & $\begin{array}{l}\text { Salacia mamba N. } \\
\text { Hallé }\end{array}$ & & $\cong$ & & -7 & & & & & & & J & a & & & & & & & & & & & & & & & & & & & $\Re$ \\
\hline GC & $\mathrm{McPh}$ & Méso & Sarco & $\begin{array}{l}\mathrm{bm}+ \\
\mathrm{sm}\end{array}$ & Burseraceae & $\begin{array}{l}\text { Santiria trimera } \\
\text { (Oliv.) Aubr. }\end{array}$ & & $\infty$ & 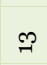 & $\infty$ & $\infty$ & -1 & & & & & J & $\infty$ & & $\infty$ & - & N & N & $m$ & $\rightarrow$ & 4 & $\infty$ & & & & N & & & -7 & & & f \\
\hline GC & $\mathrm{McPh}$ & Micro & Sarco & $\mathrm{sm}$ & Araliaceae & $\begin{array}{l}\text { Schefflera barteri } \\
\text { (Seem.) Harms }\end{array}$ & & & & & & & & a & & & & & & & - & & & - & & & & & & & & & & & & & N \\
\hline GC & $\mathrm{McPh}$ & Micro & Sarco & sm & Anacardiaceae & $\begin{array}{l}\text { Sorindeia grandifolia } \\
\text { Engl. }\end{array}$ & & & 4 & - & $\stackrel{\circ}{\infty}$ & 10 & & -1 & & & हे & 9 & & เ & 6 & 10 & & & & & & & & & - & & & & & & 8 \\
\hline At & $\mathrm{MsPh}$ & Méso & Sarco & $\begin{array}{l}\mathrm{bm}+ \\
\mathrm{sm}\end{array}$ & Malvaceae & $\begin{array}{l}\text { Sterculia } \\
\text { tragacantha Lindl. }\end{array}$ & & & & -1 & & & & & & & & & & & & & & & & - & & & & & & & & & & & -1 \\
\hline GC & $\mathrm{McPh}$ & Méso & Sarco & $\mathrm{bm}$ & Olacaceae & $\begin{array}{l}\text { Strombosia } \\
\text { grandifolia Hook. f. } \\
\text { ex Benth. }\end{array}$ & & & - & & & $\infty$ & & -1 & & & $\infty$ & & & & & -1 & - & & & & & & & & & & & & & & 10 \\
\hline Aam & $\mathrm{MsPh}$ & Méso & Sarco & Large & Olacaceae & $\begin{array}{l}\text { Strombosia pustulata } \\
\text { Oliv. }\end{array}$ & N & -1 & -1 & $\infty$ & + & + & & -7 & & a & a & & & + & - & & $\infty$ & - & N & - & - & - & -1 & - & - & & & & & & $\stackrel{\infty}{\sim}$ \\
\hline BG & $\mathrm{McPh}$ & Méso & Pogo & $\begin{array}{l}\mathrm{bm}+ \\
\mathrm{sm}\end{array}$ & Apocynaceae & $\begin{array}{l}\text { Strophanthus } \\
\text { thollonii Franch. }\end{array}$ & 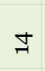 & $\hat{~}$ & & -1 & & & & t & -7 & $r$ & 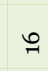 & $\approx$ & & $\infty$ & & $r$ & & & & & & & & & & & & & & & ले \\
\hline G & $\mathrm{MsPh}$ & Micro & Sarco & sm & Myrtaceae & $\begin{array}{l}\text { Syzygium staudtii } \\
\text { (Engl.) Mildbr. }\end{array}$ & & & - & & & & & & & & & & & & & & & & & & - & & & & & & & & & & -7 \\
\hline At & $\mathrm{McPh}$ & Micro & Sarco & $\mathrm{sm}_{\mathrm{mi}}+$ & Apocynaceae & $\begin{array}{l}\text { Tabernaemontana } \\
\text { ventricosa } \\
\text { Hochst.ex A. DC. }\end{array}$ & & & -1 & & - & & & เ & -7 & $\infty$ & $\infty$ & -1 & & N & $\infty$ & & a & - & & & - & & & & & & & & & & $\cong$ \\
\hline CG & $\mathrm{McPh}$ & Micro & Sarco & $\begin{array}{l}\mathrm{bm}+ \\
\mathrm{sm}\end{array}$ & Apocynaceae & $\begin{array}{c}\text { Tabernaemontana } \\
\text { inconspicua Stapf }\end{array}$ & $\nabla$ & & & & & & & & & & - & - & & & $r$ & & -7 & & & & & & & & & & & & & & r \\
\hline
\end{tabular}




\begin{tabular}{|c|c|c|c|c|c|c|c|c|c|c|c|c|c|c|c|c|c|c|c|c|c|c|c|c|c|c|c|c|c|c|c|c|c|c|c|c|}
\hline \multirow[b]{2}{*}{$\hat{H}$} & \multirow[b]{2}{*}{ 电 } & \multirow[b]{2}{*}{ 药 } & \multirow[b]{2}{*}{ 国 } & \multirow[b]{2}{*}{$\vec{I}$} & \multirow[b]{2}{*}{ 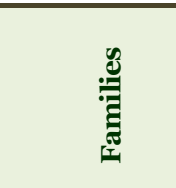 } & \multirow[b]{2}{*}{$\begin{array}{l}\text { है } \\
\text { है } \\
\text { के }\end{array}$} & \multicolumn{11}{|c|}{ Plots } & \multicolumn{19}{|c|}{ Average class of diameter } \\
\hline & & & & & & & 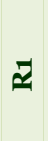 & ฆ & $\ddot{\varkappa}$ & $\mathbb{\pm}$ & $\stackrel{20}{2}$ & $\stackrel{2}{\simeq}$ & $\approx$ & $\stackrel{\infty}{\varkappa}$ & & 2 & $\stackrel{0}{2}$ & $\stackrel{10}{10}$ & คิ & ค̊ & $\stackrel{10}{9}$ & คी & $\stackrel{10}{8}$ & $\stackrel{10}{\hat{n}}$ & $\begin{array}{l}10 \\
0 \\
0\end{array}$ & ถ̊ & $\stackrel{10}{0}$ & $=$ & ถี่ & ڤ̊n & I8 & مी & $\stackrel{10}{0}$ & $\stackrel{10}{\stackrel{10}{a}}$ & $\stackrel{\infty 0}{\rightarrow}$ & : \\
\hline GC & $\mathrm{McPh}$ & Méso & Sarco & $\mathrm{mi}$ & Rubiaceae & $\begin{array}{l}\text { Tarenna eketensis } \\
\text { Wernham }\end{array}$ & & & & & & & & & & & -7 & & -7 & & & & & & & & & & & & & & & & & $\neg$ \\
\hline CG & Phgr & Micro & Scléro & sm & Acanthaceae & $\begin{array}{l}\text { Mendoncia gilgiana } \\
\text { (Lindau) Benoist }\end{array}$ & & -7 & & & & & & & & & & & -7 & & & & & & & & & & & & & & & & & - \\
\hline GC & Phgr & Micro & Scléro & $\mathrm{sm}$ & Acanthaceae & $\begin{array}{l}\text { Thunbergia } \\
\text { vogeliana Benth. }\end{array}$ & & & & 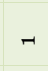 & & & & & & & & -7 & & & & & & & & & & & & & & & & & & -1 \\
\hline AM & $\mathrm{MsPh}$ & Macro & Sarco & $\mathrm{bm}$ & Moraceae & $\begin{array}{l}\text { Treculia africana } \\
\text { Decne var.africana }\end{array}$ & -7 & & & & & & & & & & & & & & $r$ & & & & & & & & & & & & & & & - \\
\hline At & $\mathrm{McPh}$ & Méso & Sarco & $\underset{\mathrm{mi}}{\mathrm{sm}}+$ & Rubiaceae & $\begin{array}{l}\text { Tricalysia pallens } \\
\text { Hiern }\end{array}$ & & N & + & N & + & & & & & -7 & & $a$ & is & -7 & $r$ & & & $r$ & & & & & & & & & & & & $\widehat{\widehat{\theta}}$ \\
\hline GC & $\mathrm{McPh}$ & Méso & Sarco & $\begin{array}{l}\mathrm{bm}+ \\
\mathrm{sm}\end{array}$ & Meliaceae & $\begin{array}{l}\text { Trichilia prieureana } \\
\text { A.Juss.subsp.vermo } \\
\text { esenii J.J.de Wilde }\end{array}$ & $\infty$ & 6 & & -1 & & $r$ & & & & & & $\bullet$ & + & -7 & & & & & & & -7 & & & & & & & & & $\cong$ \\
\hline CG & $\mathrm{MsPh}$ & Méso & Sarco & Large & Meliaceae & $\begin{array}{l}\text { Trichilia rubescens } \\
\text { Oliv. }\end{array}$ & 0 & & $\infty$ & & N & $\infty$ & & & & $m$ & a & I & -7 & & N & & a & - & & N & & & $r$ & & & & & & & $\tilde{\vartheta}$ \\
\hline CG & $\mathrm{MsPh}$ & Méso & Sarco & sm & Anacardiaceae & $\begin{array}{l}\text { Trichoscypha } \\
\text { acuminata Engl. }\end{array}$ & & $\wedge$ & & & & N & & & & & & 0 & - & & $r$ & & -1 & & & & & & & & & & & & & $a$ \\
\hline At & $\mathrm{McPh}$ & Méso & Sarco & sm & Anacardiaceae & $\begin{array}{l}\text { Trichoscypha lucens } \\
\text { Oliv. }\end{array}$ & & - & & & & & & & & & & -1 & & & & & & & & & & & & & & & & & & - \\
\hline BG & $\mathrm{MsPh}$ & Méso & Sarco & sm & Anacardiaceae & $\begin{array}{l}\text { Trichoscypha mannii } \\
\text { Hook. f. }\end{array}$ & & & & & - & & & & & & & & -7 & & & & & & & & & & & & & & & & & - \\
\hline GC & $\mathrm{MsPh}$ & Méso & Sarco & $\begin{array}{l}\mathrm{bm}+ \\
\mathrm{sm}\end{array}$ & Meliaceae & $\begin{array}{l}\text { Turraeanthus } \\
\text { africanus (Welw.ex } \\
\text { C.CD.) Pellegr. }\end{array}$ & 10 & $\infty$ & & & & 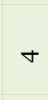 & & & & & & $\wedge$ & & & $r$ & & & & & & - & & N & -7 & -7 & & & & & $m$ \\
\hline GC & Phgr & Méso & Scléro & $\mathrm{mi}$ & Urticaceae & $\begin{array}{l}\text { Urera repens } \\
\text { (Wedd.) Rendle }\end{array}$ & & & & & & & & & & - & & -7 & & & & & & & & & & & & & & & & & & - \\
\hline CG & $\mathrm{McPh}$ & Micro & Sarco & $\mathrm{sm}_{\mathrm{mi}}^{+}$ & Opiliaceae & $\begin{array}{l}\text { Urobotrya congolana } \\
\text { (Baill.) Hiepko } \\
\text { subsp.congolana }\end{array}$ & $\rightarrow$ & -1 & & & & & & - & & -7 & 10 & N & $r$ & $r$ & $\infty$ & & & & - & -7 & & & & & & & & & & $a$ \\
\hline At & $\mathrm{McPh}$ & Méso & Sarco & sm & Annonaceae & $\begin{array}{l}\text { Uvaria angolensis } \\
\text { Welw.ex Oliv. }\end{array}$ & & -1 & & & & & & & & & & -1 & & & & & & & & & & & & & & & & & & -1 \\
\hline BG & $\mathrm{McPh}$ & Méso & Sarco & $\begin{array}{l}\mathrm{bm}+ \\
\mathrm{sm}\end{array}$ & Annonaceae & $\begin{array}{l}\text { Uvariodendron } \\
\text { giganteum (Engl.) } \\
\text { R. E. Fr. }\end{array}$ & $r$ & & & - & & & & & & & & -1 & $-r$ & & & & & & & & & & & & & & & & & a \\
\hline CG & $\mathrm{McPh}$ & Méso & Sarco & sm & Annonaceae & $\begin{array}{l}\text { Uvariopsis } \\
\text { vanderystii Robyns } \\
\text { \& Ghesq }\end{array}$ & & & N & & & & & & & & & -1 & & & & $-r$ & & & & & & & & & & & & & & N \\
\hline At & $\mathrm{McPh}$ & Micro & Sarco & $\underset{\mathrm{mi}}{\mathrm{sm}}+$ & Annonaceae & $\begin{array}{l}\text { Xylopia aethiopica } \\
\text { (Dunal) A. Rich. }\end{array}$ & & & 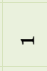 & & & & & N & v & & a & & & N & $r$ & $r$ & & $r$ & & & & & & & & & & & & 10 \\
\hline GC & $\mathrm{MsPh}$ & Méso & Sarco & $\mathrm{sm}$ & Rutaceae & $\begin{array}{l}\text { Zanthoxylum gilletii } \\
\text { (De Wild) } \\
\text { Waterman }\end{array}$ & & N & & & $\tau$ & & & & & & & -1 & & & & $\rightarrow$ & & & & & -7 & & & & & & & & & $\infty$ \\
\hline GC & $\mathrm{McPh}$ & Micro & Sarco & $\begin{array}{l}\mathrm{bm}+ \\
\mathrm{sm}\end{array}$ & Rutaceae & $\begin{array}{l}\text { Zanthoxylum } \\
\text { rubescens Hook. } \mathrm{f}\end{array}$ & - & & & & & & & & & & & & - & & & & & & & & & & & & & & & & & -7 \\
\hline \multirow[t]{2}{*}{ CG } & $\mathrm{MsPh}$ & Micro & Sarco & $\mathrm{mi}$ & Anacardiaceae & $\begin{array}{l}\text { Sorindeia winkleri } \\
\text { Engl. }\end{array}$ & & & & & & & & & & & - & & & & & & - & & & & & & & & & & & & & - \\
\hline & & & & & & Total & ปี & $\stackrel{+}{=}$ & $\hat{\mathrm{o}}$ & है & हे & $\underline{0}$ & ⿳亠丷厂 & $\infty$ & 61 & \& & స్ & î & ไู & 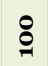 & A & 10 & 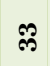 & $\bar{m}$ & $\stackrel{?}{2}$ & สี & สิ & t & $\infty$ & $\infty$ & $\infty$ & N & $\infty$ & $\pi$ & $\pi$ & $\stackrel{\infty}{=}$ \\
\hline
\end{tabular}


Appendix 2. The 51 families with their values of relative dominance, relative density, relative diversity and FIV in decreasing order.

\begin{tabular}{|c|c|c|c|c|c|c|c|}
\hline Families & $\begin{array}{l}\text { Relative dominance } \\
{[\times 100 \%]}\end{array}$ & Families & $\begin{array}{l}\text { Relative density } \\
{[\times 100 \%]}\end{array}$ & Families & $\begin{array}{l}\text { Relative diversity } \\
{[\times 100 \%]}\end{array}$ & Families & $\begin{array}{l}\text { FIV } \\
{[\times 300 \%]}\end{array}$ \\
\hline Meliaceae & 20.74 & Meliaceae & 17.27 & Rubiaceae & 10.89 & Meliaceae & 41.22 \\
\hline Euphobiaceae & 14.78 & Rubiaceae & 13.70 & Euphorbiaceae & 7.69 & Rubiaceae & 32.40 \\
\hline Burseraceae & 10.61 & Burseraceae & 10.00 & Annonaceae & 7.05 & Euphorbiaceae & 30.94 \\
\hline Malvaceae & 10.61 & Menispermaceae & 9.96 & Sapindaceae & 5.69 & Malvaceae & 23.55 \\
\hline Clusiaceae & 9.65 & Malvaceae & 9.09 & Moraceae & 4.48 & Burseraceae & 21.25 \\
\hline Rubiaceae & 7.81 & Euphorbiaceae & 8.47 & Anacardiaceae & 3.85 & Clusiaceae & 20.13 \\
\hline Olacaceae & 6.98 & Clusiaceae & 7.27 & Malvaceae & 3.85 & Moraceae & 17.24 \\
\hline Moraceae & 6.40 & Olacaceae & 7.27 & Leguminosae & 3.21 & Anacardiaceae & 15.57 \\
\hline Apocynaceae & 5.38 & Anacardiaceae & 7.26 & Clusiaceae & 3.21 & Olacaceae & 15.53 \\
\hline Leguminosae & 4.77 & Moraceae & 6.36 & Meliaceae & 3.21 & Sapotaceae & 14.29 \\
\hline Sapotaceae & 4.72 & Sapotaceae & 6.36 & Sapotaceae & 3.21 & Menispermaceae & 13.78 \\
\hline Anacardiaceae & 4.46 & Apocynaceae & 4.84 & Rutaceae & 2.56 & Annonaceae & 13.05 \\
\hline Annonaceae & 4.05 & Sapindaceae & 4.66 & Apocynaceae & 1.92 & Sapindaceae & 12.80 \\
\hline Thymeliaceae & 3.58 & Leguminosae & 4.55 & Combretaceae & 1.92 & Leguminosae & 12.53 \\
\hline Lauraceae & 3.22 & Lauraceae & 4.55 & Flacourtiaceae & 1.92 & Apocynaceae & 12.14 \\
\hline Menispermaceae & 3.10 & Combretaceae & 4.28 & Lauraceae & 1.92 & Myristicaceae & 10.74 \\
\hline Myrtaceae & 2.57 & Thymeliaceae & 3.07 & Piperaceae & 1.92 & Lauraceae & 9.69 \\
\hline Sapindaceae & 2.45 & Caricaceae & 2.73 & Simaroubaceae & 1.92 & Combretaceae & 8.02 \\
\hline Combretaceae & 1.82 & Myristicaceae & 2.73 & Vitaceae & 1.92 & Thymeliaceae & 7.93 \\
\hline Caricaceae & 1.62 & Celastraceae & 2.70 & Acanthaceae & 1.28 & Myrtaceae & 6.27 \\
\hline Families & $\begin{array}{l}\text { Relative dominance } \\
{[\times 100 \%]}\end{array}$ & Families & $\begin{array}{l}\text { Relative density } \\
{[\times 100 \%]}\end{array}$ & Families & $\begin{array}{l}\text { Relative diversity } \\
{[\times 100 \%]}\end{array}$ & Families & $\begin{array}{l}\text { FIV } \\
{[\times 300 \%]}\end{array}$ \\
\hline Alangiaceae & 1.51 & Myrtaceae & 2.42 & Agavaceae & 1.28 & Celastraceae & 5.27 \\
\hline Celastraceae & 1.30 & Annonaceae & 1.96 & Araliaceae & 1.28 & Caricaceae & 4.99 \\
\hline Opiliaceae & 1.23 & Araliaceae & 1.82 & Celastraceae & 1.28 & Araliaceae & 4.01 \\
\hline Araliaceae & 0.92 & Opiliaceae & 1.82 & Icacinaceae & 1.28 & Rutaceae & 3.47 \\
\hline Rutaceae & 0.87 & Alangiaceae & 0.91 & Melastomataceae & 1.28 & Alangiaceae & 3.06 \\
\hline Myristicaceae & 0.82 & Rhamnaceae & 0.91 & Myristicaceae & 1.28 & Piperaceae & 2.92 \\
\hline Bignoniaceae & 0.67 & Rutaceae & 0.91 & Myrtaceae & 1.28 & Simaroubaceae & 2.73 \\
\hline Rosaceae & 0.59 & Piperaceae & 0.84 & Ochnaceae & 1.28 & Vitaceae & 2.59 \\
\hline Melastomataceae & 0.58 & Bignoniaceae & 0.65 & Olacaceae & 1.28 & Melastomataceae & 2.51 \\
\hline Rhamnaceae & 0.56 & Leeaceae & 0.65 & Thymeliaceae & 1.28 & Flacourtiaceae & 2.48 \\
\hline Violaceae & 0.39 & Melastomataceae & 0.65 & Alangiaceae & 0.64 & Opiliaceae & 2.19 \\
\hline
\end{tabular}

T. J. M. Tchoua and E. Noumi (2016) / Structure and Floristic Diversity of the Woody Vegetation of the Mount Kupe Submontane Forest (Moungo - Cameroon) 


\begin{tabular}{|c|c|c|c|c|c|c|c|}
\hline Families & $\begin{array}{l}\text { Relative dominance } \\
{[\times 100 \%]}\end{array}$ & Families & $\begin{array}{l}\text { Relative density } \\
{[\times 100 \%]}\end{array}$ & Families & $\begin{array}{l}\text { Relative diversity } \\
{[\times 100 \%]}\end{array}$ & Families & $\begin{array}{l}\text { FIV } \\
{[\times 300 \%]}\end{array}$ \\
\hline Cecropiaceae & 0.34 & Simaroubaceae & 0.56 & Bignoniaceae & 0.64 & Rhamnaceae & 2.11 \\
\hline Vitaceae & 0.30 & Agavaceae & 0.47 & Boraginaceae & 0.64 & Bignoniaceae & 1.96 \\
\hline Flacourtiaceae & 0.28 & Tiliaceae & 0.47 & Burseraceae & 0.64 & Agavaceae & 1.94 \\
\hline Polygalaceae & 0.28 & Vitaceae & 0.37 & Caricaceae & 0.64 & Ochnaceae & 1.69 \\
\hline Tiliaceae & 0.26 & Flacourtiaceae & 0.28 & Cecropiaceae & 0.64 & Icacinaceae & 1.64 \\
\hline Simaroubaceae & 0.25 & Icacinaceae & 0.28 & Comariopsidaceae & 0.64 & Acanthaceae & 1.53 \\
\hline Cyatheaceae & 0.24 & Passifloraceae & 0.28 & Cyatheaceae & 0.64 & Leeaceae & 1.44 \\
\hline Ochnaceae & 0.23 & Acanthaceae & 0.19 & Lecythidaceae & 0.64 & Tiliaceae & 1.37 \\
\hline Boraginaceae & 0.22 & Cyatheaceae & 0.19 & Leeaceae & 0.64 & Rosaceae & 1.33 \\
\hline Lecythidaceae & 0.21 & Lecythidaceae & 0.19 & Menispermaceae & 0.64 & Violaceae & 1.13 \\
\hline Agavaceae & 0.19 & Ochnaceae & 0.19 & Octoknemaceae & 0.64 & Cecropiaceae & 1.07 \\
\hline Piperaceae & 0.16 & Boraginaceae & 0.09 & Opiliaceae & 0.64 & Cyatheaceae & 1.06 \\
\hline Leeaceae & 0.15 & Cecropiaceae & 0.09 & Passifloraceae & 0.64 & Lecythidaceae & 1.04 \\
\hline Peripiocaceae & 0.10 & Comariopsidaceae & 0.09 & Peripiocaceae & 0.64 & Polygalaceae & 1.02 \\
\hline Icacinaceae & 0.08 & Octoknemaceae & 0.09 & Polygalaceae & 0.64 & Passifloraceae & 0.97 \\
\hline Octoknemaceae & 0.08 & Peripiocaceae & 0.09 & Rhamnaceae & 0.64 & Boraginaceae & 0.95 \\
\hline Acanthaceae & 0.06 & Polygalaceae & 0.09 & Rosaceae & 0.64 & Peripiocaceae & 0.84 \\
\hline Passifloraceae & 0.05 & Rosaceae & 0.09 & Tiliaceae & 0.64 & Octoknemaceae & 0.82 \\
\hline Urticaceae & 0.02 & Urticaceae & 0.09 & Urticaceae & 0.64 & Urticaceae & 0.75 \\
\hline Comariopsidaceae & 0.01 & Violaceae & 0.09 & Violaceae & 0.64 & Comariopsidaceae & 0.74 \\
\hline
\end{tabular}


Appendix 3. The 156 species with their basal areas; their relative frequency, relative density, relative dominance and IVI in decreasing order.

\begin{tabular}{|c|c|c|c|c|c|c|}
\hline Species & $\begin{array}{l}\text { Number of } \\
\text { individuals }\end{array}$ & $\begin{array}{l}\text { Basal } \\
\text { area } \\
{\left[\mathrm{m}^{2}\right]}\end{array}$ & $\begin{array}{l}\text { Relative } \\
\text { fréquency } \\
{[x \times 100 \%]}\end{array}$ & 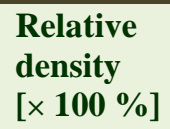 & $\begin{array}{l}\text { Relative } \\
\text { dominance } \\
{[\times 100 \%]}\end{array}$ & $\begin{array}{l}\text { IVI } \\
{[\times 300 \%]}\end{array}$ \\
\hline Santiria trimera (Oliv.) Aubr. & 47 & 9.59 & 5.06 & 3.97 & 10.61 & 19.64 \\
\hline Carapa procera D.C & 20 & 9.92 & 7.59 & 1.69 & 10.03 & 19.31 \\
\hline Cola acuminata (P.Beau.) Schott et Endl. & 44 & 7.86 & 6.33 & 3.72 & 5.51 & 15.56 \\
\hline Penianthus longifolius Miers & 107 & 1.74 & 1.67 & 9.96 & 3.09 & 14.72 \\
\hline Drypetes leonensis Pax & 46 & 6.82 & 3.80 & 3.89 & 5.32 & 13.01 \\
\hline Strombosia pustulata Oliv. & 18 & 7.84 & 3.80 & 1.52 & 6.98 & 12.30 \\
\hline Turraeanthus africana (Welw. ex C. CD.) Pellegr. & 13 & 6.39 & 3.80 & 1.09 & 6.69 & 11.58 \\
\hline Pycnanthus angolensis (Welw.) Warb. & 12 & 6.23 & 2.53 & 1.01 & 6.73 & 10.27 \\
\hline Englerophytum stelechanthum K. Krause & 33 & 3.83 & 3.80 & 2.79 & 3.28 & 9.87 \\
\hline Allanblackia gabonensis Oliv. & 12 & 3.54 & 1.79 & 3.01 & 3.92 & 8.72 \\
\hline Ficus sur Forssk. & 9 & 3.99 & 1.89 & 3.12 & 3.71 & 8.72 \\
\hline Trichilia rubescens Oliv. & 23 & 4.09 & 3.80 & 1.75 & 3.17 & 8.72 \\
\hline Garcinia lucida Vesque & 21 & 2.77 & 1.59 & 2.77 & 4.19 & 8.56 \\
\hline Sorindeia grandifolia Engl. & 66 & 1.73 & 1.34 & 4.08 & 3.08 & 8.50 \\
\hline Macaranga occidentalis (Müll. Arg.) Müll. Arg. & 11 & 3.52 & 1.00 & 1.02 & 6.28 & 8.31 \\
\hline Beilschmiedia crassipes (Engl. \& K. Krause) Robyns \& Wilezek & 13 & 2.15 & 2.53 & 5.84 & 2.84 & 8.21 \\
\hline Cylicomorpha somlsii (Urb.) Urb. & 5 & 1.46 & 3.79 & 2.73 & 1.62 & 8.14 \\
\hline Garcinia smeathmannii (Planch. \& Triana) Oliv. & 11 & 2.18 & 2.61 & 1.84 & 3.45 & 7.89 \\
\hline Psychotria sp. aff. subobliqua Hiern & 48 & 0.72 & 1.67 & 4.47 & 1.29 & 7.43 \\
\hline Eugenia obanensis Bak. F & 27 & 1.88 & 2.34 & 2.42 & 2.57 & 7.33 \\
\hline Strophathus thollonii Franch. & 37 & 1.17 & 1.67 & 3.45 & 2.09 & 7.21 \\
\hline Drypetes preussii (Pax) Hutch. & 15 & 3.79 & 2.53 & 1.82 & 2.85 & 7.20 \\
\hline Cola grandifolia & 28 & 2.92 & 1.34 & 2.42 & 2.97 & 6.73 \\
\hline Newtonia duncanthomasii Mackinder \& Cheek & 6 & 1.89 & 1.94 & 2.19 & 2.19 & 6.31 \\
\hline Psychotria globosa Hiern var. globosa & 29 & 1.43 & 1.00 & 2.70 & 2.56 & 6.26 \\
\hline Trichilia prieureana A. Juss. subsp. vermoesenii J.J. de Wilde & 12 & 1.02 & 2.94 & 1.93 & 1.30 & 6.17 \\
\hline Beilschmiedia acuta Kosterm. & 9 & 1.42 & 1.59 & 2.47 & 1.90 & 5.98 \\
\hline Urobotrya congolana (Baill.) Kiepko subsp. congolana & 9 & 1.66 & 2.53 & 1.82 & 1.27 & 5.62 \\
\hline Tabernaemontana ventricosa Hochst. ex A. DC. & 11 & 1.37 & 2.01 & 1.02 & 2.44 & 5.47 \\
\hline Placodiscus opacus Radlk. & 35 & 0.66 & 1.00 & 3.26 & 1.17 & 5.43 \\
\hline Dicranolepis vestita Engl. & 22 & 1.04 & 1.34 & 2.05 & 1.85 & 5.24 \\
\hline Tricalysia pallens Hiern & 17 & 0.80 & 2.01 & 1.58 & 1.43 & 5.02 \\
\hline Xylopia aethiopica (Durand) A. Rich & 5 & 1.70 & 1.00 & 0.47 & 3.04 & 4.51 \\
\hline Chrysophyllum lacourtianum De Wild. & 4 & 0.84 & 2.27 & 1.19 & 1.05 & 4.51 \\
\hline Zanthoxylum gilletii (De Wild) Waterman & 3 & 0.99 & 1.94 & 1.09 & 1.23 & 4.26 \\
\hline Nauclea diderrichii (De Wild. \& Th. Dur. ) Merrill & 1 & 1.77 & 1.27 & 0.91 & 1.96 & 4.14 \\
\hline Polyscias fulva (Hiern) Harms & 2 & 0.69 & 1.94 & 1.19 & 0.96 & 4.09 \\
\hline Combretum bracteatum (M. A. Lawson) Engl. \& Diels & 19 & 0.37 & 1.34 & 1.77 & 0.67 & 3.77 \\
\hline
\end{tabular}

T. J. M. Tchoua and E. Noumi (2016) / Structure and Floristic Diversity of the Woody Vegetation of the Mount Kupe Submontane Forest (Moungo - Cameroon) 


\begin{tabular}{|c|c|c|c|c|c|c|}
\hline Species & $\begin{array}{l}\text { Number of } \\
\text { individuals }\end{array}$ & $\begin{array}{l}\text { Basal } \\
\text { area } \\
{\left[\mathrm{m}^{2}\right]}\end{array}$ & $\begin{array}{l}\text { Relative } \\
\text { fréquency } \\
{[x \times 100 \%]}\end{array}$ & $\begin{array}{l}\text { Relative } \\
\text { density } \\
{[\times 100 \%]}\end{array}$ & $\begin{array}{l}\text { Relative } \\
\text { dominance } \\
{[\times 100 \%]}\end{array}$ & $\begin{array}{l}\text { IVI } \\
{[\times 300 \%]}\end{array}$ \\
\hline Parkia bicolor A. Chev. & 1 & 1.43 & 1.27 & 0.91 & 1.58 & 3.76 \\
\hline Ficus mucuso Welw. ex Ficalho & 4 & 0.83 & 1.59 & 1.19 & 0.95 & 3.73 \\
\hline Cola cauliflora Mast. & 5 & 1.15 & 1.00 & 0.47 & 2.05 & 3.51 \\
\hline Schefflera barteri (Seem.) Harms & 2 & 0.60 & 1.59 & 0.99 & 0.77 & 3.37 \\
\hline Cola verticillata (Thonn.) Stapf. ex A. Chev. & 1 & 1.00 & 1.27 & 0.91 & 1.11 & 3.28 \\
\hline Crotonogyne preussii $\mathrm{Pax}$ & 1 & 1.00 & 1.27 & 0.91 & 1.11 & 3.28 \\
\hline Anonidium mannii (Oliv.) Engl. \& Diels & 2 & 0.59 & 1.59 & 0.99 & 0.68 & 3.27 \\
\hline Psychotria pedoncularis (Salisb.) Steyerm. var. pedoncularis & 12 & 0.41 & 1.34 & 1.12 & 0.73 & 3.18 \\
\hline Octolepis casearia Oliv. & 11 & 0.97 & 0.33 & 1.02 & 1.73 & 3.09 \\
\hline Antiaris toxicaria var. welwistchii (Engl.) & 1 & 0.79 & 1.27 & 0.91 & 0.87 & 3.04 \\
\hline Ficus ottoniifolia (Miq.) Miq. subsp. Ottoniifolia & 1 & 0.79 & 1.27 & 0.91 & 0.87 & 3.04 \\
\hline Syzygium staudtii (Engl.) Milbr. & 1 & 0.79 & 1.27 & 0.91 & 0.87 & 3.04 \\
\hline Garcinia mannii Oliv. & 6 & 0.24 & 2.01 & 0.56 & 0.43 & 3.00 \\
\hline Chrysophyllum africanum A. DC. & 1 & 0.67 & 1.27 & 0.91 & 0.74 & 2.91 \\
\hline Klaineanthus gaboniae Pierre ex Prain & 1 & 0.64 & 1.27 & 0.91 & 0.70 & 2.88 \\
\hline Sterculia tragacatha Lindl. & 1 & 0.64 & 1.27 & 0.91 & 0.70 & 2.88 \\
\hline Daniella oliveri (Rolfe) Hutch. \& Dalziel & 1 & 0.61 & 1.27 & 0.91 & 0.68 & 2.85 \\
\hline Alchornea floribunda Müll. Arg. & 16 & 0.18 & 1.00 & 1.49 & 0.33 & 2.82 \\
\hline Salacia mamba N. Hallé & 13 & 0.48 & 0.67 & 1.21 & 0.86 & 2.74 \\
\hline Erythrina mildbraedii Harms & 1 & 0.50 & 1.27 & 0.91 & 0.56 & 2.73 \\
\hline Hypodaphnis zenkeri (Engl.) Stapf & 1 & 0.50 & 1.27 & 0.91 & 0.56 & 2.73 \\
\hline Maesopsis eminii Engl. & 1 & 0.50 & 1.27 & 0.91 & 0.56 & 2.73 \\
\hline Combretaceae Liane & 15 & 0.36 & 0.67 & 1.40 & 0.65 & 2.71 \\
\hline Eriocoelum petiolare Radlk. & 1 & 0.46 & 1.27 & 0.91 & 0.50 & 2.68 \\
\hline Combretum paniculatum Vent. & 12 & 0.29 & 1.00 & 1.12 & 0.51 & 2.63 \\
\hline Cleistopholis patens (Benth.) Engl. \& Diels & 1 & 0.39 & 1.27 & 0.91 & 0.43 & 2.60 \\
\hline Salacia loloensis Loes. var loloensis & 16 & 0.24 & 0.67 & 1.49 & 0.43 & 2.59 \\
\hline Laccodiscus ferrugineus (Baker) Radlk. & 7 & 0.49 & 1.00 & 0.65 & 0.87 & 2.53 \\
\hline Ixora guineensis Benth. & 8 & 0.19 & 1.34 & 0.75 & 0.33 & 2.42 \\
\hline Strombosia grandifolia Hook. ex. Benth. & 5 & 0.53 & 1.00 & 0.47 & 0.95 & 2.42 \\
\hline Trichoscypha acuminata Engl. & 9 & 0.44 & 0.67 & 0.84 & 0.78 & 2.29 \\
\hline Memecylon dasyanthum Gilg \& Ledermann ex Engl. & 5 & 0.27 & 1.00 & 0.47 & 0.49 & 1.96 \\
\hline Leea guineensis $G$. Don & 7 & 0.08 & 1.00 & 0.65 & 0.15 & 1.80 \\
\hline Rothmannia hispida (K. Schum.) Fagerlind & 8 & 0.20 & 0.67 & 0.75 & 0.35 & 1.77 \\
\hline Desplatsia dewevrei (De W ild. \& T. Durand) & 5 & 0.15 & 1.00 & 0.47 & 0.26 & 1.73 \\
\hline Alangium chinense (Lour.) Harms & 1 & 1.37 & 1.27 & 0.91 & 1.51 & 1.69 \\
\hline Canthium vulgare (K. Schum.) Bullock & 9 & 0.08 & 0.67 & 0.84 & 0.15 & 1.66 \\
\hline Kigelia africana (Lam.) Benth. & 7 & 0.38 & 0.33 & 0.65 & 0.67 & 1.66 \\
\hline Chrysophyllum welwistchii Engl. & 2 & 0.40 & 0.67 & 0.19 & 0.72 & 1.58 \\
\hline Tabernaemontana inconspicua Stapf & 4 & 0.48 & 0.33 & 0.37 & 0.85 & 1.56 \\
\hline
\end{tabular}

T. J. M. Tchoua and E. Noumi (2016) / Structure and Floristic Diversity of the Woody Vegetation of the Mount Kupe Submontane Forest (Moungo - Cameroon) 


\begin{tabular}{|c|c|c|c|c|c|c|}
\hline Species & $\begin{array}{l}\text { Number of } \\
\text { individuals }\end{array}$ & $\begin{array}{l}\text { Basal } \\
\text { area } \\
{\left[\mathrm{m}^{2}\right]}\end{array}$ & $\begin{array}{l}\text { Relative } \\
\text { fréquency } \\
{[x \times 100 \%]}\end{array}$ & $\begin{array}{l}\text { Relative } \\
\text { density } \\
{[\times 100 \%]}\end{array}$ & $\begin{array}{l}\text { Relative } \\
\text { dominance } \\
{[\times 100 \%]}\end{array}$ & $\begin{array}{l}\text { IVI } \\
{[\times 300 \%]}\end{array}$ \\
\hline Leptonychia pallida K. Schum. & 5 & 0.05 & 1.00 & 0.47 & 0.08 & 1.55 \\
\hline Entandrophragma angolensis (Welw.) C.D & 4 & 0.08 & 1.00 & 0.37 & 0.13 & 1.51 \\
\hline Monodora brevipes Benth. & 5 & 0.09 & 0.67 & 0.47 & 0.17 & 1.30 \\
\hline Coffea bakossii Cheek \& Bridson & 3 & 0.17 & 0.67 & 0.28 & 0.31 & 1.25 \\
\hline Psychotria succulenta (Hiern) Petit & 6 & 0.17 & 0.33 & 0.56 & 0.31 & 1.20 \\
\hline Piper capense Schumach \& Thonn. Cf. & 4 & 0.04 & 0.67 & 0.37 & 0.07 & 1.12 \\
\hline Allophylus bullatus Radlk & 3 & 0.05 & 0.67 & 0.28 & 0.09 & 1.04 \\
\hline Brucea guineensis G. Don & 3 & 0.05 & 0.67 & 0.28 & 0.09 & 1.04 \\
\hline Prunus africana (Hook. f) Kalkm & 1 & 0.33 & 0.33 & 0.09 & 0.59 & 1.02 \\
\hline Dracaena fragrans (L) Ker-Gawl. & 3 & 0.03 & 0.67 & 0.28 & 0.06 & 1.01 \\
\hline Barteria solida Breteler & 3 & 0.03 & 0.67 & 0.28 & 0.05 & 1.00 \\
\hline Dracaena sp. aff. phrynioides Hook. & 2 & 0.07 & 0.67 & 0.19 & 0.13 & 0.99 \\
\hline Coelocaryon preussii Warb. & 1 & 0.31 & 0.33 & 0.09 & 0.56 & 0.98 \\
\hline Uvariodendron giganteum (Engl.) R. E. Fr. & 2 & 0.05 & 0.67 & 0.19 & 0.09 & 0.95 \\
\hline Sorindeia winkleri Engl. & 1 & 0.28 & 0.33 & 0.09 & 0.50 & 0.93 \\
\hline Uvariopsis vanderystii Robyns \& Ghesq & 2 & 0.20 & 0.33 & 0.19 & 0.36 & 0.88 \\
\hline Rinorea gabunensis Engl. & 1 & 0.22 & 0.33 & 0.09 & 0.39 & 0.82 \\
\hline Piper umbellatum Linn. & 4 & 0.04 & 0.33 & 0.37 & 0.06 & 0.77 \\
\hline $\begin{array}{l}\text { Alchornea hirtella Benth. fa. Glabata (Müll. Arg.) Pax \& } \\
\text { K. Hoffm. }\end{array}$ & 2 & 0.13 & 0.33 & 0.19 & 0.24 & 0.76 \\
\hline Cyathea camerooniana Hook. var. zenkeri (Diels) Tardieu & 2 & 0.13 & 0.33 & 0.19 & 0.24 & 0.76 \\
\hline Musanga cecropioides $\mathrm{R}$. Br. ex. Tedlie & 1 & 0.19 & 0.33 & 0.09 & 0.34 & 0.76 \\
\hline Crateranthus talbotii Bak. f. & 2 & 0.12 & 0.33 & 0.19 & 0.21 & 0.73 \\
\hline Carpolobia alba G. Don & 1 & 0.16 & 0.33 & 0.09 & 0.28 & 0.71 \\
\hline Neoboutonia mannii Benth. var. mannii & 2 & 0.08 & 0.33 & 0.19 & 0.14 & 0.66 \\
\hline Quassia silvestris Cheek \& Jondlind ined. & 2 & 0.08 & 0.33 & 0.19 & 0.14 & 0.66 \\
\hline Antidesma laciniantum Müll. Arg. var. laciniantum & 1 & 0.13 & 0.33 & 0.09 & 0.22 & 0.65 \\
\hline Cordia aurantiaca Bak. & 1 & 0.13 & 0.33 & 0.09 & 0.22 & 0.65 \\
\hline Homalium africanum (Hook. f.) Benth. & 1 & 0.12 & 0.33 & 0.09 & 0.21 & 0.64 \\
\hline Ouratea reticulata (P. Beauv.) Engl. & 1 & 0.11 & 0.33 & 0.09 & 0.20 & 0.63 \\
\hline Memecylon griseo-violaceum Gilg \& Ledermann ex. Engl. & 2 & 0.05 & 0.33 & 0.19 & 0.09 & 0.62 \\
\hline Treculia africana Decne var. Africana & 1 & 0.11 & 0.33 & 0.09 & 0.19 & 0.62 \\
\hline Cissus amoena Gilg \& Brandt & 2 & 0.05 & 0.33 & 0.19 & 0.09 & 0.61 \\
\hline Monodora tenuifolia Benth. & 1 & 0.10 & 0.33 & 0.09 & 0.18 & 0.61 \\
\hline Mammea africana Sabine & 2 & 0.04 & 0.33 & 0.19 & 0.08 & 0.60 \\
\hline Ficus exasperata $\mathrm{Vahl}$ & 1 & 0.06 & 0.33 & 0.09 & 0.11 & 0.57 \\
\hline Isolona zenkeri Engl. & 2 & 0.02 & 0.33 & 0.19 & 0.04 & 0.56 \\
\hline Antidesma vogelianum Müll. Arg. & 2 & 0.02 & 0.33 & 0.19 & 0.03 & 0.55 \\
\hline Coffea montekupensis Stoffelen & 1 & 0.07 & 0.33 & 0.09 & 0.12 & 0.55 \\
\hline Lasianthera africana P. Beauv. & 2 & 0.02 & 0.33 & 0.19 & 0.03 & 0.55 \\
\hline
\end{tabular}

T. J. M. Tchoua and E. Noumi (2016) / Structure and Floristic Diversity of the Woody Vegetation of the Mount Kupe Submontane Forest (Moungo - Cameroon) 


\begin{tabular}{|c|c|c|c|c|c|c|}
\hline Species & $\begin{array}{l}\text { Number of } \\
\text { individuals }\end{array}$ & $\begin{array}{l}\text { Basal } \\
\text { area } \\
{\left[\mathrm{m}^{2}\right]}\end{array}$ & $\begin{array}{l}\text { Relative } \\
\text { fréquency } \\
{[x \times 100 \%]}\end{array}$ & $\begin{array}{l}\text { Relative } \\
\text { density } \\
{[\times 100 \%]}\end{array}$ & $\begin{array}{l}\text { Relative } \\
\text { dominance } \\
{[\times 100 \%]}\end{array}$ & $\begin{array}{l}\text { IVI } \\
{[\times 300 \%]}\end{array}$ \\
\hline Cissus barbeyana De Wild. \& T. Durand & 1 & 0.06 & 0.33 & 0.09 & 0.11 & 0.54 \\
\hline Cryptolepis sanguinolenta (Lindl.) Schltr. & 1 & 0.06 & 0.33 & 0.09 & 0.10 & 0.53 \\
\hline Aningeria robusta (A. Chev.) Aubrév. \& Pellegr. & 1 & 0.05 & 0.33 & 0.09 & 0.09 & 0.52 \\
\hline Cissus aralioides (Welw. ex. Baker) Planch & 1 & 0.05 & 0.33 & 0.09 & 0.10 & 0.52 \\
\hline Monodora myristica (Gaertn.) Duanal & 1 & 0.05 & 0.33 & 0.09 & 0.10 & 0.52 \\
\hline Allophylus africanus P. Beauv. var. africanus & 1 & 0.05 & 0.33 & 0.09 & 0.09 & 0.51 \\
\hline Octoknema genovefae Villiers & 1 & 0.05 & 0.33 & 0.09 & 0.08 & 0.51 \\
\hline Clausena anisata (Wild.) Hook. f. ex Benth. & 1 & 0.04 & 0.33 & 0.09 & 0.07 & 0.50 \\
\hline Cuviera longiflora Hiern & 1 & 0.04 & 0.33 & 0.09 & 0.07 & 0.50 \\
\hline Eriocoelum racemosum Baker & 1 & 0.04 & 0.33 & 0.09 & 0.07 & 0.50 \\
\hline Deinbollia rambaensis Pellegr. & 1 & 0.03 & 0.33 & 0.09 & 0.06 & 0.48 \\
\hline Icacina mannii Oliv. & 1 & 0.03 & 0.33 & 0.09 & 0.06 & 0.48 \\
\hline Oxyanthus pallidus Hiern & 1 & 0.03 & 0.33 & 0.09 & 0.06 & 0.48 \\
\hline Trichoscypha mannii Hook. f. & 1 & 0.03 & 0.33 & 0.09 & 0.06 & 0.48 \\
\hline Zanthoxylum rubescens Hook. f. & 1 & 0.03 & 0.33 & 0.09 & 0.06 & 0.48 \\
\hline Caloncoba glauca (P. Beauv.) Gilg & 1 & 0.03 & 0.33 & 0.09 & 0.05 & 0.47 \\
\hline Mallotus oppositifolius (Geisel.) Müll. Arg. & 1 & 0.03 & 0.33 & 0.09 & 0.05 & 0.47 \\
\hline Mendoncia gilgiana (Lindau) Benoist & 1 & 0.03 & 0.33 & 0.09 & 0.05 & 0.47 \\
\hline Campylospermum elongatum (Oliv.) Tiegh. & 1 & 0.02 & 0.33 & 0.09 & 0.04 & 0.46 \\
\hline Ficus trichopoda Baker & 1 & 0.02 & 0.33 & 0.09 & 0.04 & 0.46 \\
\hline Gardenia vogelii Hook. f. ex Planch. & 1 & 0.02 & 0.33 & 0.09 & 0.04 & 0.46 \\
\hline Lannea welwitschii (Hiern) Engl. & 1 & 0.02 & 0.33 & 0.09 & 0.04 & 0.46 \\
\hline Rutidea glabra Hiern & 1 & 0.02 & 0.33 & 0.09 & 0.04 & 0.46 \\
\hline Tarenna eketensis Wernham & 1 & 0.02 & 0.33 & 0.09 & 0.04 & 0.46 \\
\hline Adenocarpus mannii (Hook. f.) Hook. f. & 1 & 0.01 & 0.33 & 0.09 & 0.02 & 0.45 \\
\hline Oncoba ovalis Oliv. & 1 & 0.01 & 0.33 & 0.09 & 0.02 & 0.45 \\
\hline Peperomia pellucida (L.) Kunth & 1 & 0.01 & 0.33 & 0.09 & 0.02 & 0.45 \\
\hline Urera repens (Wedd.) Rendle & 1 & 0.01 & 0.33 & 0.09 & 0.02 & 0.45 \\
\hline Uvaria angolensis Welw. ex Oliv. & 1 & 0.01 & 0.33 & 0.09 & 0.02 & 0.45 \\
\hline Allophylus grandifolius (Baker) Radlk. & 1 & 0.02 & 0.33 & 0.09 & 0.01 & 0.44 \\
\hline Artabotrys congolensis De Wild \& T. Durand & 1 & 0.01 & 0.33 & 0.09 & 0.01 & 0.44 \\
\hline Bolbitis gaboonensis (Hook.) Alston & 1 & 0.01 & 0.33 & 0.09 & 0.01 & 0.44 \\
\hline Deinbollia sp. aff. maxima Gilg & 1 & 0.01 & 0.33 & 0.09 & 0.01 & 0.44 \\
\hline Erythrococca anomala (Juss. ex Poir.) Prain & 1 & 0.01 & 0.33 & 0.09 & 0.01 & 0.44 \\
\hline Oricia lecomteana Pierre & 1 & 0.01 & 0.33 & 0.09 & 0.01 & 0.44 \\
\hline Psychotria gabonia Hiern & 1 & 0.01 & 0.33 & 0.09 & 0.01 & 0.44 \\
\hline Quassia sanguinea Cheek \& Jondlind ined. & 1 & 0.01 & 0.33 & 0.09 & 0.01 & 0.44 \\
\hline Thunbergia vogeliana Benth. & 1 & 0.01 & 0.33 & 0.09 & 0.01 & 0.44 \\
\hline Trichoscypha lucens Oliv. & 1 & 0.01 & 0.33 & 0.09 & 0.01 & 0.44 \\
\hline
\end{tabular}


Appendix 4. Rough and balanced spectres of phytogéographic type (TP), biologic type (TB), leaf types (TF), spore type (TD) and steep type (TH) of the species recorded in Mount Kupe submontane forest.
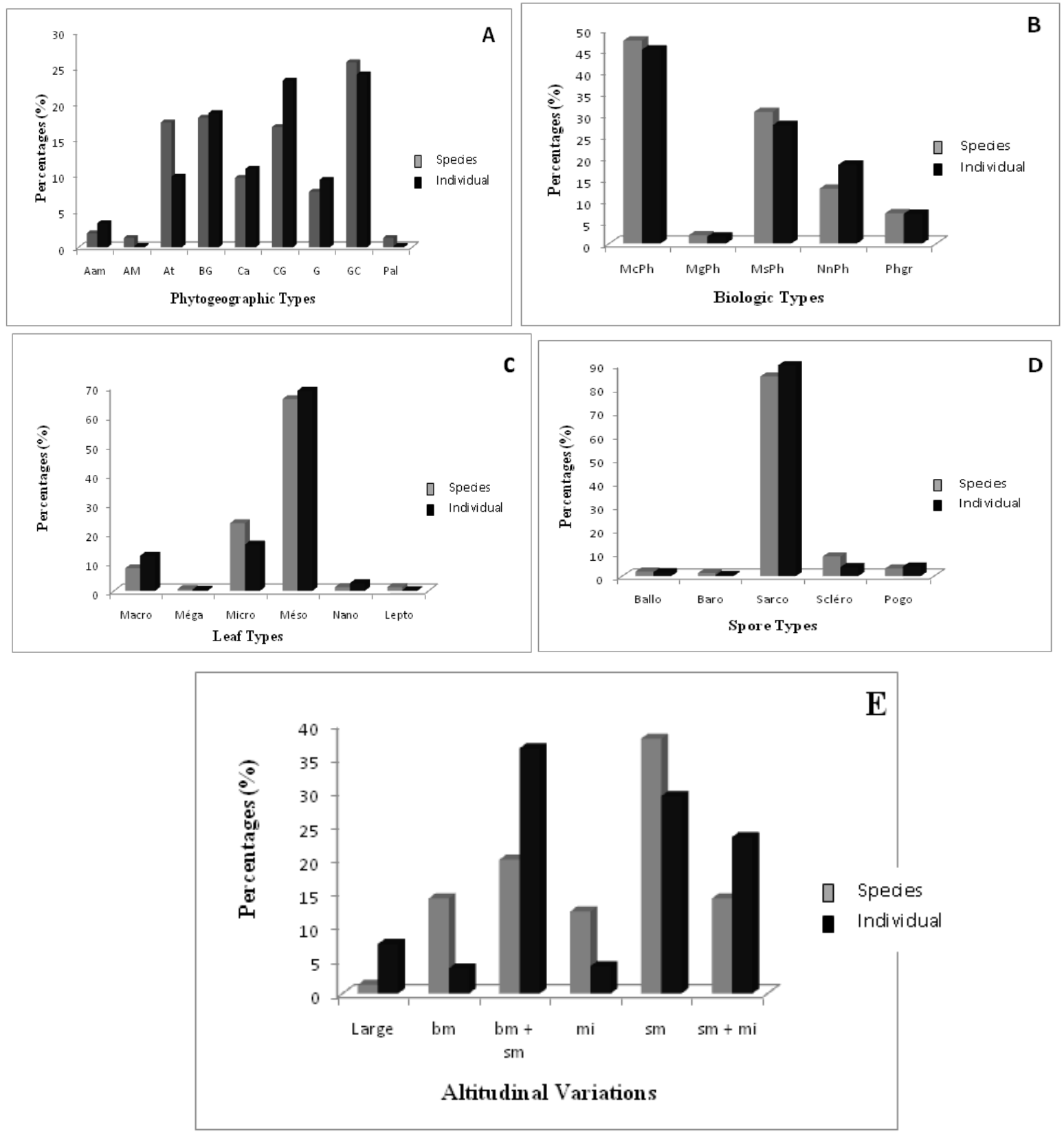

\section{How to cite this article:}

Tchoua, T. J. M., Noumi, E., 2016. Structure and floristic diversity of the woody vegetation of the Mount Kupe submontane forest (Moungo - Cameroon). Int. J. Curr. Res. Biosci. Plant Biol. 3(1), 1-26. doi: http://dx.doi.org/10.20546/ijcrbp.2016.301.001 